\title{
Strengthening Gender Justice in a Just Transition: A Research Agenda Based on a Systematic Map of Gender in Coal Transitions
}

\author{
Paula Walk ${ }^{1, *}$, Isabell Braunger ${ }^{1,2,3}$, Josephine Semb ${ }^{1}$, Carolin Brodtmann ${ }^{1}$, Pao-Yu Oei ${ }^{1,2,3}{ }^{(1 D}$ and \\ Claudia Kemfert ${ }^{3,4}$ \\ 1 Workgroup for Economic and Infrastructure Policy (WIP), TU Berlin, Straße des 17. Juni 135, \\ 10623 Berlin, Germany; ib@wip.tu-berlin.de (I.B.); jos@wip.tu-berlin.de (J.S.); cb@wip.tu-berlin.de (C.B.); \\ pyo@wip.tu-berlin.de (P.-Y.O.) \\ 2 Center for Sustainable Energy Systems (ZNES), Europa-Universität Flensburg, 10117 Berlin, Germany \\ 3 Department of Energy, Transportation, Environment, DIW Berlin, Mohrenstraße 58, 10117 Berlin, Germany; \\ sekretariat-evu@diw.de \\ 4 Institute of Sustainability Governance, Leuphana University, 21335 Lüneburg, Germany \\ * Correspondence: pw@wip.tu-berlin.de
}

Citation: Walk, P.; Braunger, I.; Semb, J.; Brodtmann, C.; Oei, P.-Y.; Kemfert, C. Strengthening Gender Justice in a Just Transition: A Research Agenda Based on a Systematic Map of Gender in Coal Transitions. Energies 2021, 14, 5985. https://doi.org/10.3390/ en14185985

Academic Editor: Maxim Tyulenev

Received: 5 August 2021

Accepted: 9 September 2021

Published: 21 September 2021

Publisher's Note: MDPI stays neutral with regard to jurisdictional claims in published maps and institutional affiliations.

Copyright: (c) 2021 by the authors. Licensee MDPI, Basel, Switzerland. This article is an open access article distributed under the terms and conditions of the Creative Commons Attribution (CC BY) license (https:// creativecommons.org/licenses/by/ $4.0 /)$.

\begin{abstract}
For climate change mitigation, a rapid phase-out of fossil fuels such as coal is necessary. This has far-reaching gender-specific consequences. This paper presents a systematic map of the literature that examines the impact of historical coal phase-out processes on women and their role in these processes. The search process consisted of screening over 3100 abstracts and reading 247 fulltext studies. The analysis of the 73 publications ultimately included in the systematic map shows that past coal phase-outs meant both opportunities (e.g., increased labour market participation) as well as burdens for women (e.g., double burden of job and household). It becomes clear that agency within coal transitions was also gendered. For example, it was difficult for women to gain access to union structures, which led them to organise themselves into grassroots movements. Our research shows that policies aiming for a just sustainability transition should always be explicitly gender-responsive. However, the impact of sustainability transitions on women's lives remains largely under-researched. Therefore, we propose a research agenda based on our findings containing six key issues that need to be addressed scientifically.
\end{abstract}

Keywords: gender; coal phase-out; just transition; women; systematic map; research agenda

\section{Introduction}

All sectors of the economy (e.g., agriculture, transport, industry) will need to undergo deep decarbonisation to achieve a limit of global warming below 1.5 or 2 degrees, as stipulated in the Paris Agreement [1]. These low-carbon transitions have a gender dimension, since they affect women in different ways than they affect men [2]. The changes might be adverse for women because of their lower financial resources and thus their inability to compensate for their emissions or to purchase low-emission technologies. Furthermore, women are still responsible for the majority of care work (e.g., cooking, washing), which leads to higher energy consumption and thus $\mathrm{CO}_{2}$ emissions. Furthermore, women often work in less secure jobs with a lower level of unionization, which could lead to (uncompensated) job losses in case of structural change. These differences in conditions (lower financial resources, less time available due to care work, etc.) also mean that women have less agency and opportunity to promote their interests and viewpoints in the political arena, where transition policies are decided [3]. However, low-carbon transitions could also help overcome such gendered power structures. For example, there is evidence that in the transport sector, the sustainability transition towards greater use of public transport and increased development of cycling and walking infrastructure benefits women; men use cars more often, while women are more likely to walk, cycle and use public transport [2]. 
Such examples show that a better understanding of the gender dynamics of low-carbon transitions is very much needed to develop gender-sensitive transition policies [3]. Therefore, a sound data basis is required. However, gender-segregated and gender-specific data are lacking in most sectors and areas so far.

Our paper is an attempt to start filling in this research gap by systematically collecting scientific evidence on the impact on women of low-carbon transitions and the role that women played-referred to as agency. Based on that data collection, we develop a research agenda to systematically advance research on gender and transitions. We focus on the example of coal transitions, because they are essential building blocks on the way to a sustainable economy. Coal is still responsible for more than $40 \%$ of global $\mathrm{CO}_{2}$ emissions [4]. There will only be a chance to comply with the Paris Agreement if a global coal phaseout is achieved in a timely manner [5,6]. Structural change processes from coal have a gender dimension on several levels. There are significantly more men working in the coal industry (e.g., in 2017, 78.4\% of the workforce in the US coal industry was male [7]). The division of labour between the sexes tends to be more pronounced in coal regions, as the employment rate of women in coal regions is often lower than the national average (see, e.g, [8] for Silesia, Poland and [9] for Appalachia, US). Furthermore, there is an increasing amount of literature that elaborates on the connection of the coal industry with masculine norms [10-12].

In the first step of our research approach (see Figure 1), we conducted a systematic map $[13,14]$ of the existing evidence on the nexus between gender and coal transitions across a wide range of disciplines, such as anthropology, sociology, and economics. A systematic map is a methodology to collect, describe, and catalogue existing evidence on a specific topic in a comprehensive and repeatable way. Systematic maps provide information about the state-of-the-art of the field of interest, such as the amount of existing literature on methodological approaches and scientific disciplines [13,15]. Therefore, this methodology fits well to answer our research question: What evidence exists about the effects of coal transitions on women in contrast to men and about female agency during coal transitions?
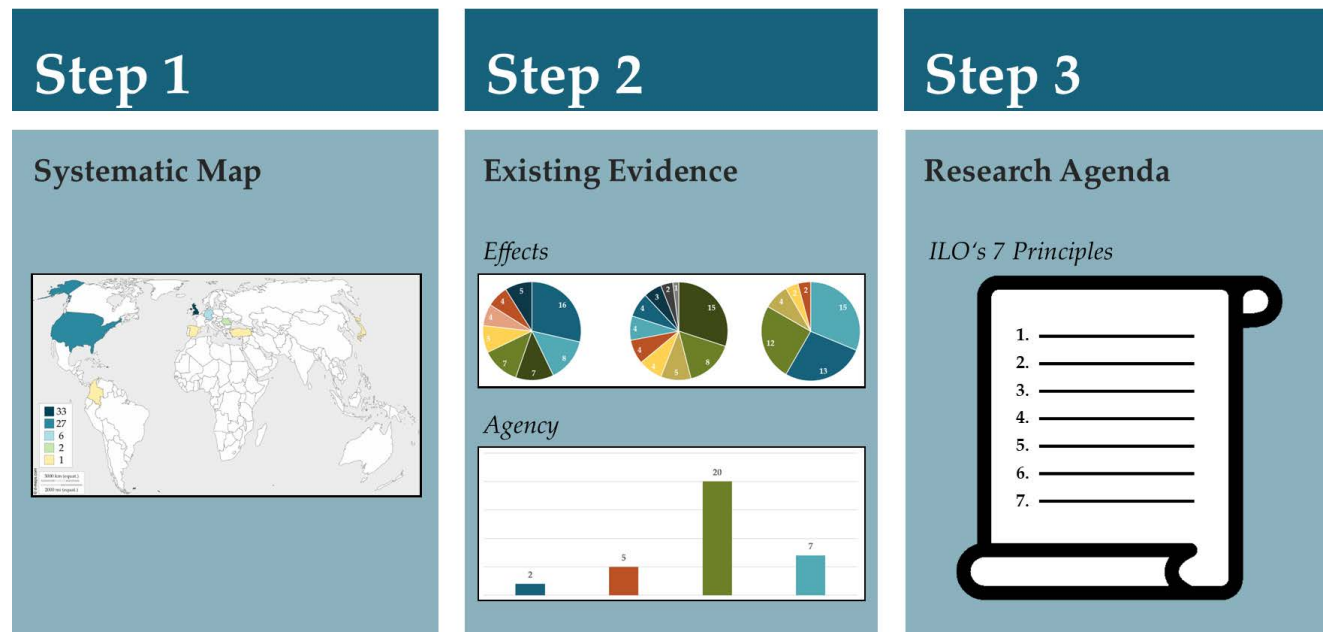

Figure 1. Overview of our research approach. Source: Own depiction, using resources from [16].

Our search strategy consisted of a database search in Scopus, EBSCO, Web of Science, and ProQuest, a grey literature search, and a call for relevant literature in the scientific community; this was supplemented by snowballing the references of relevant publications. The literature search, and the subsequent full-text reading of 247 publications, yielded 73 relevant studies, mostly focusing on countries in the Global North (mainly the UK, the USA, and Germany).

In a second step (see Figure 1), we systematically extracted all information in the publications according to what impact historical coal transitions had on women and what 
role women played in each transition. We found that across country contexts, the long-term employment effects of past coal transitions were that the (mostly male) miners in coal regions increasingly left the labour force due to early retirement or redundancy, while women increasingly sought employment-giving them an increased degree of financial independence. However, many of them had to take up precarious jobs, which were mainly located in the service sector and provided little financial and planning security. Turning towards women's agency, our analysis showed that women active in the political struggle around various historical coal transitions tended to organise themselves in less institutionalised ways compared to men (partly because institutions such as unions were difficult for women to enter). Their activism, for example, in the miners' strike in the UK or in anti-coal activism opposing Mountain-Top Removal (MTR) in the USA, usually took place in self-organised grassroots movements or through involvement in community work.

In recent years, there have been increasing calls to equitably share the costs and burdens of a low-carbon transition among all stakeholders, which is summarised by the term "just transition" [17-19]. We acknowledge that the design of a just transition depends very much on the geographical, social, and political context [10]. The conviction that a just transition also includes gender justice is fortunately becoming more widespread [17]. However, research looking at the social outcome of low-carbon transitions is often limited to calculating net employment effects [20]. Therefore, based on our research results and as the third step (see Figure 1) of our research approach, we develop a research agenda. The agenda identifies where research is still lacking concerning the gendered aspects of low-carbon transitions. Through the agenda, we aim to stimulate further research on this topic, the results of which will help policymakers better incorporate gender considerations into policies aimed to shape a just transition. To better systematise and structure the research agenda, we use the International Labour Organisation's (ILO) seven "Guidelines for a just transition towards environmentally sustainable economies and societies for all" [17] (p. 6). Although the ILO's concept of just transition has some shortcomings, it has been successfully anchored in important international policy documents by the UN and the EU, such as the Paris Agreement [20-22]. Future research should ask about policies designed to improve working conditions in the service sector and create well-paid jobs for all genders in the Green Economy sectors. In addition, many studies reported an increased total workload for women, as their domestic responsibilities remained, but a new responsibility as wage earners was added. One important area of research to inform policymakers is the availability of care services in carbon-intensive regions and the extent to which missing support infrastructure prevents women from planning their own careers. Furthermore, future research should investigate the main interests, needs, and concerns of women affected by the transition and the kinds of activities and forms of organisation they choose. First, this would make women's activism more visible, and second, it would inform state institutions how to make the transition process more inclusive. It is also important to investigate how women's access to resources, such as adequate funding or access to policymakers and institutions, could be improved so that they are able to better integrate their interests into the political process.

The remainder of the paper is structured as follows: Section 2 presents our methodological approach - the systematic map. Section 3 summarises the information we have extracted from the publications. Based on those results, Section 4 presents our research agenda on how future research on just transition pathways can more comprehensively take into account gender dimensions. Section 5 concludes.

\section{Methodology—Systematic Map}

We answer our research question "what evidence exists about the effects of coal transitions on women in comparison to men and about female agency within coal transitions?" using a systematic map. A systematic map is well-suited to answer this question, since it is designed to collect, describe, and catalogue existing evidence on a specific topic in a comprehensive and repeatable way. In doing so, it provides information about the 
current scientific state of the field of interest, such as the amount of existing literature, as well as geographical foci, methodological approaches, and scientific disciplines. A systematic map can also help to identify research gaps or controversies in the existing literature $[13,14,23]$. The results of our systematic map therefore provide a good basis for developing a research agenda.

To start our research process, we developed a systematic map protocol, which included the research idea, question and aim, inclusion and exclusion criteria, and search strategy. After having received feedback on it from experts in the field, it became the basis of our methodological procedure. In the following, we describe the four stages of our methodological approach.

\subsection{Development of the Search String}

Our research question includes the two basic terms: coal transition and agency. Before we present our methodological approach, it is important to provide a definition of these two terms and present our concept of gender, which is also essential to our work.

We define a coal transition as a (regional) decline in the extraction or combustion of coal or a substantial loss of jobs in the coal industry. This definition allows us to include smaller, regional coal transitions and honours the social significance they bear. We define the concept of agency as "the property or capacity of actors to make things happen" [24] (p. 11). We conceptualise actors not merely as individuals, separate from their society, but as unique parts of a collective, who make choices based on the structurally presupposed rationales surrounding them, rather than simply autonomously [25].

In our study, we use gender as an analytical tool to make socioeconomic inequalities that affect women visible.We share the notions of modern feminist theories on the relationship between sex and gender; however, to be able to extract the relevant information from existing literature for this study, we had to conceptualise the category "women" as a socially constructed but direct consequence of the female sex. This is a very simplified approach to gender, but we consider it appropriate for our research interest. It would be beyond the scope of this paper to comprehensively present the findings of gender research (for a more elaborate and differentiated discussion of gender, see for example [26,27]). Being assigned to the category "woman" generally goes along with gendered norms that lead to constraints, while being assigned to the category "man" commonly brings more privileges [28]. One of the assumptions that goes along with the category "woman" is being a caregiver and socially oriented. Thus, women are expected to do most of the unpaid care work, related to both the physical as well as the emotional well-being of people. Care work is essential for the functioning of a society, but its value is barely recognised, neither in economic terms nor as a high-skilled and energy-intensive activity. The time and energy women invest in care work is no longer available for other activities, which could bring higher status, therefore limiting their own life chances in comparison to men. If a person does not fulfil gendered norms, this behaviour is accompanied by social sanctions. It is essential to note that women are not a homogeneous group, but have very different life situations depending, e.g., on age, socioeconomic background, place of origin, and race. Still, women have on average less access to resources (e.g., finances, influence on decision-making) than men and consequently different opportunities in life. Women's social positioning not only influences how transitions affect them, but also their agency within coal transitions, for example, regarding their political articulation, their forms of organisation, or their representation in decision-making bodies.

In an iterative process, we developed a search string based on these three central terms. A search string is designed to find as many relevant publications as possible when using it in databases. It consists of several categories including synonyms or similar terms. We used one category for coal (e.g., lignite, mining), one for gender (e.g., women, woman), and one for transition and agency (see Table 1). Transition and agency were grouped into one category to ensure that either a transition moment is directly covered or questions 
of agency are addressed, which might point towards a transition in process (e.g., strike, activis *).

Table 1. Search terms by research category.

\begin{tabular}{|c|c|c|}
\hline Transition and Agency & Coal & Gender \\
\hline $\begin{array}{c}\text { transition * } \\
\text { transformation * } \\
\text { change * } \\
\text { reform } \\
\text { closure * } \\
\text { decreas * } \\
\text { declin * } \\
\text { collapse * } \\
\text { crises } \\
\text { crisis } \\
\text { strik * } \\
\text { resistance } \\
\text { protest * } \\
\text { agency } \\
\text { activis * } \\
\text { oppos * }\end{array}$ & $\begin{array}{c}\text { coal } \\
\text { lignite } \\
\text { mining } \\
\text { anthracite * (anthracites) } \\
\text { miner } \\
\text { miners } \\
\text { coalfield * } \\
\text { coalmin * } \\
\text { coalface } \\
\text { AND NOT "data mining" } \\
\text { AND NOT "text mining" }\end{array}$ & $\begin{array}{l}\text { gender * } \\
\text { woman * } \\
\text { women * } \\
\text { female * } \\
\text { mother * } \\
\text { femini * } \\
{ }^{*} \text { wives } \\
{ }^{*} \text { wife }\end{array}$ \\
\hline
\end{tabular}

Note: Terms within a category are connected using the Boolean operator OR. The categories are connected by AND, requiring each record to refer to all three categories. Additionally, wildcards $\left(^{*}\right)$ serve to include different endings to the same word stem.

We collected a broad range of relevant search terms for all three categories, which allowed us to detect records across disciplines and times of publication-these might differ starkly in their terminology while still addressing the same topics. A preliminary search was conducted to evaluate the relevance of the terms, and a benchmark test with five relevant publications was established (test list). Text mining software was used to analyse the results of the test search and identify further relevant search terms. With this process, we came up with a comprehensive as well as consistent search string (see Table 1).

\subsection{Inclusion and Exclusion Criteria}

At first, unsystematic pre-tests allowed us to grasp an idea of the scope of existing literature and the exact inclusion and exclusion criteria needed to identify relevant literature. Following the PICO (Population, Intervention, Comparator (since our research is mostly based on qualitative case studies, a Comparator is not applicable), Outcome) format, we identified the key inclusion and exclusion criteria (Table 2) [29]: Population encompasses people living in coal-intensive regions worldwide, Interventions includes coal transitions as defined above, and Outcome relates to gender-related social, political, economic, and demographic effects, as well as gendered agency within these transitions. To gather a comprehensive literature base, books, reports, conference papers, theses, and working papers as well as journal articles were included in the systematic map.

Combining this with the aforementioned PICO categories, we identified the following inclusion/exclusion criteria. 
Table 2. Inclusion and exclusion criteria.

\begin{tabular}{lll}
\hline \multicolumn{1}{c}{ Inclusion } & \multicolumn{1}{c}{ Exclusion } \\
\hline - $\begin{array}{l}\text { Population: focus on coal regions } \\
\text { Intervention: historical coal transition } \\
\text { moment (decline in coal production or } \\
\text { coal-related employment) covered }\end{array}$ & - & $\begin{array}{l}\text { Only information on masculinity or male } \\
\text { perspectives }\end{array}$ \\
$\begin{array}{l}\text { Outcome: gendered information-effects } \\
\text { on women or female agency }\end{array}$ & - & $\begin{array}{l}\text { research } \\
\text { Scenarios or policy recommendations for } \\
\text { future transitions }\end{array}$ \\
Publication in English, German, or & - $\begin{array}{l}\text { Non-scientific literature, e.g., newspaper } \\
\text { articles, personal accounts such as diaries }\end{array}$ \\
Spanish & Publication not retrievable & \\
&
\end{tabular}

${ }^{1}$ Primarily, we retrieved full texts through access provided by Technische Universität Berlin (TU Berlin). In the next step, we drew on library subscriptions at Freie Universität Berlin and Humboldt-Universität zu Berlin. Where full texts were still missing, we requested articles directly from corresponding authors or made requests through Researchgate.org.

\subsection{Search for Literature}

Based on their scientific disciplines, four databases were selected to build the basis of our literature search: Scopus, EBSCO, Web of Science, and ProQuest. Since we were only interested in literature with a particular focus on coal transitions and gender, and in light of the broad selection of search terms per category, we limited the search to titles, abstracts, and keywords of publications. CADIMA, an open-source review management software, was used to organise the data [30].

The search in the databases yielded 3530 results (for a summary of the request to the databases, see Table A1, Appendix A). After removing 714 duplicates, 2816 potentially relevant records were screened for relevance at title-abstract level. To ensure agreement among the four reviewers on inclusion decisions, we conducted a consistency check using the kappa test after all reviewers had read $10 \%$ of the abstracts. The result of the kappa test was 0.62 ; this is acceptable according to common scientific practice. Any disagreements were discussed and rectified. We judged 205 records to be read at full-text level, and 43 of those proved to be both retrievable and relevant to our research question; they were thus included in the systematic map. We complemented our database search with a three-step approach to searching publications not available in our databases:

1. The search for grey literature consisted of two parts [31] and rendered nine publications for inclusion in the map:

- The use of two grey literature indexes operated by the Institute for Scientific and Technical Information (France) and by the European Institute for Gender Equality.

- A search using Google Scholar with a shortened search string, screening the first 100 results (additional results did not prove to be relevant).

2. To ask for additional literature recommendations, we established contact with the research community via email and social media. From this, eight additional records were added to the map.

3. Furthermore, we screened all bibliographies of previously included texts for potentially relevant publications (snowballing); this resulted in twelve additional publications. 
A total of 25 relevant records were identified through the non-database searches, leading to total of 68 publications (Figure 2). Publications were split into multiple studies if (a) they treated coal transitions in different nations or (b) various chapters of one book were found to be relevant. Ultimately, 73 studies were captured systematically in the codebook.

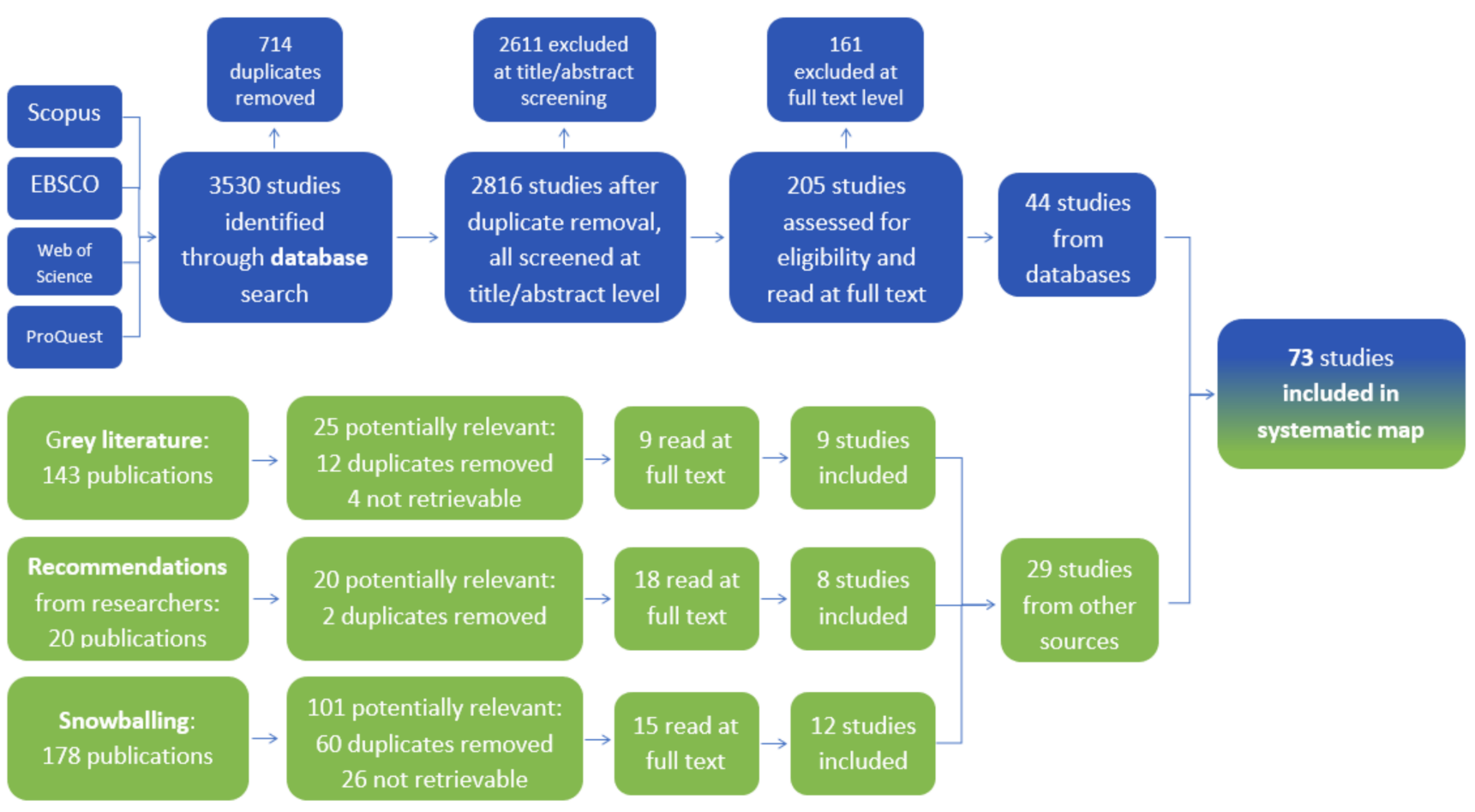

Figure 2. Detailed description of search for literature. Source: Own depiction. Note: Publications were split into multiple studies if they (a) treated coal transitions in different nations or (b) various chapters of one book were found to be relevant.

For our database search, we only used the above search string in English. We developed and tested a search string in German, but it did not yield any relevant results. We refrained from testing search strings in other languages. However, the search in English and some literature recommendations included publications in German or Spanish, which were included in our analysis. Our search string in English is certainly one reason why the publications in our systematic map predominantly deal with coal transitions in the Global North and especially in the UK and USA. It is possible that a search string in Spanish, for example, would have yielded more results on countries in the Global South (e.g., Chile has experienced a decline in coal production in recent years [32]). Moreover, it is very likely that scientific institutions in the Global North have more resources to facilitate research on this topic.

\subsection{Data-Coding Strategy}

We developed a comprehensive codebook in a multi-staged process including a testcoding phase. Table 3 presents a list of all categories and subcategories of the codebook. In addition to containing general information about the studies and coal transitions at hand (metadata), the codebook is split into two main sections to reflect the twofold research question. The first section includes information on gendered outcomes of coal transitions in five subcategories: ranging from the individual level, to the household, to the community, as well as providing information on gendered effects on job markets and the political sphere. The second part of the codebook focuses on female agency in coal transitions, and is split into different groups of female stakeholders. Moreover, we collected information on climate and environmental aspects-which ultimately proved to be disregarded in the literature we read-as well as on concepts of gender and reported intersectionality with class, race, and more. The subcategories featured a mix of fixed dropdown menus and 
open-answer fields, so that the collected data were both highly detailed and consistent among the coding team.

Table 3. Categories and subcategories.

\begin{tabular}{ll}
\hline Category & Subcategory \\
\hline Metadata & Study basics (scientific discipline, methodological design, focus of inquiry) \\
& Transition basics (dates, geography, type and scale of transitions, etc.) \\
Gender-related outcomes & Job market and economic outcomes (primary, secondary, and tertiary sectors) \\
& Political sphere \\
& Social/community level \\
& Household level \\
& Individual level \\
& Women as workers \\
Participation in coal transition & Women as male miners' relatives \\
& Women as community members \\
& Other female stakeholders \\
& Effects of female participation in transition process \\
& Men's agency and interest \\
Environmental and climate aspects & Environmental or climate aspects as drivers or outcomes of transition \\
Diversity and intersectionality & Concepts of gender \\
& Intersectionality \\
\hline
\end{tabular}

After we had read $10 \%$ of the texts from the database search, we discussed inconsistencies in the coding strategies and identified any missing or unclear categories. The codebook was adjusted slightly to ensure it included all relevant information.

\section{Gender in Historical Coal Transitions}

The 73 studies recorded in the systematic map covered gender aspects of coal transitions in eight countries: the USA, Colombia, Germany, Romania, Spain, Turkey, the UK, and Japan. Figure 3 provides an overview of the historical coal-production developments in the respective countries and summarises the main gender-related findings detailed in the following sections. It must be noted that Turkey and Colombia did not undergo a national or lasting coal transition. In the case of Turkey, the reduction in coal production remained confined to the region of Zonguldak near the Black Sea, while the decline in coal production in Colombia was only a temporary phenomenon in 2014. Nevertheless, both countries experienced a substantial decline in coal production and thereby met our inclusion criteria. Before we present our results, we would like to point out that the coal transitions in these various countries have played an important role in explaining the developments we describe below. However, there have been other social, political, and economic changes (e.g., increasing neoliberalisation in the 1980s and 1990s in the USA [33] and the UK [34]) that have influenced the situation of women, and therefore there is not always a clear causality between the coal phase-outs and the developments described. 


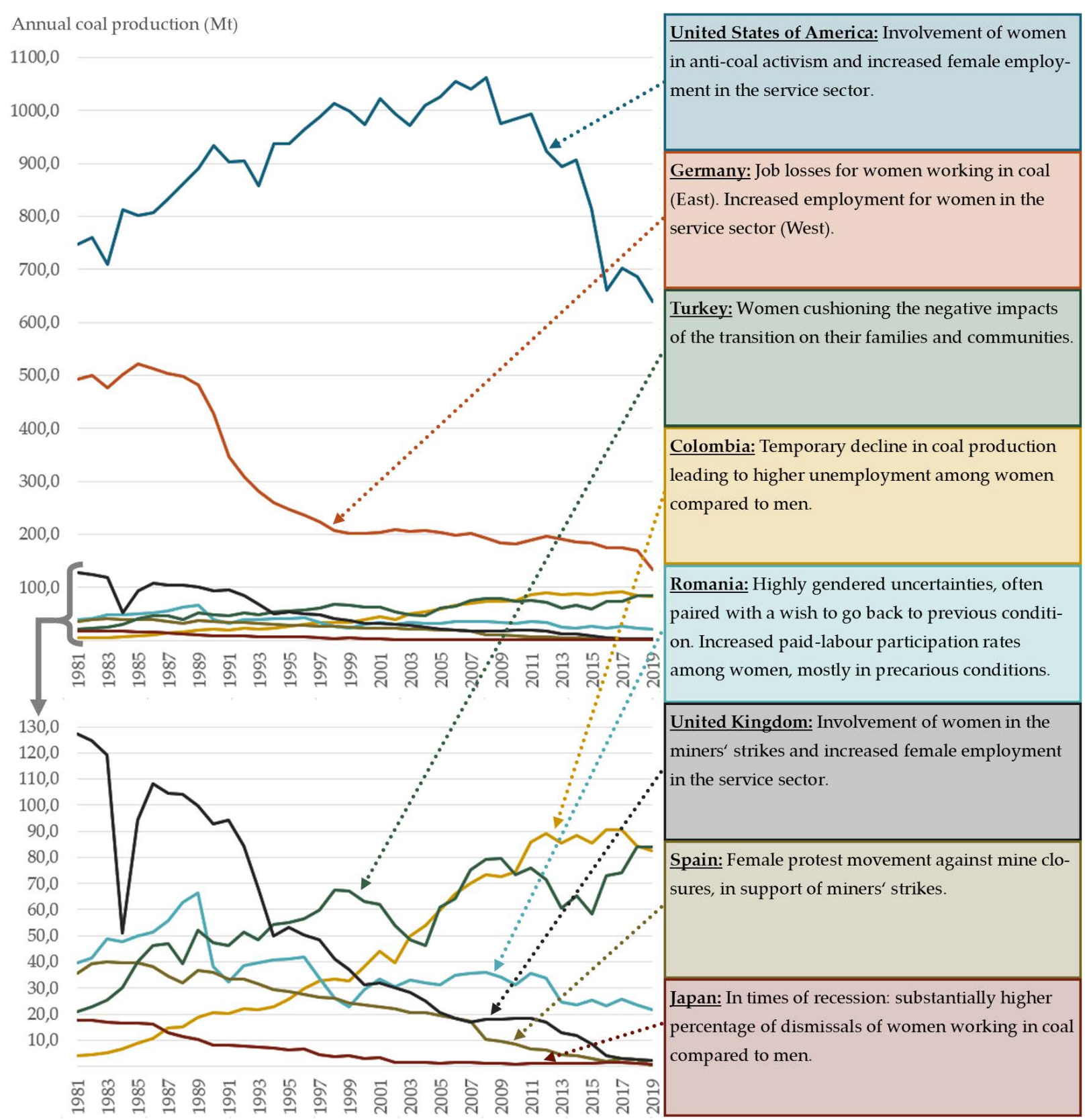

Figure 3. Transitions' overview and main reported gender aspects per country. Source: Own depiction, based on BP [35] and information collected in the codebook.

\subsection{Background Information on Studies and Coal Transitions}

Most of the studies addressed transitions in the Global North (see Figure 4a), with 33 addressing the 1920s and 1980s coal transitions in the United Kingdom [36-38], while studies concerning coal transitions in the USA follow, with 27 [39-41]. For a more detailed qualitative analysis of the research on gender aspects in the USA and UK coal transitions, see Braunger and Walk [42]. Regarding Colombia, Spain, Turkey, and Japan, there is only one study each [43-46], as well as a study by Botta [47], which covers more than one country. In our research, countries of the Global North are disproportionately represented due to our focus on historical coal transitions. Most studies stem from sociology (20/73), followed by history, geography, and political science (see Figure 4c). The majority of studies conducted were qualitative (51/73, see Figure $4 \mathrm{~b}$ ). In total, 48 out of the 73 studies were published in journals. Another 15 were book chapters, and the rest were grey literature. The vast majority of studies were written by female authors, with $31(42 \%)$ written by single 
female authors, 21 (29\%) by multiple female authors, and only 16 from single or multiple male authors $(22 \%)$. When coding the authors sex, we made a binary categorisation $(\mathrm{m} / \mathrm{f})$ based on the authors' first names. This assignment is based on our Western European cultural experiences and may additionally misgender people with queer identities. An additional five studies (7\%) appeared to have mixed authorship.

a. Geographical distribution of the studies

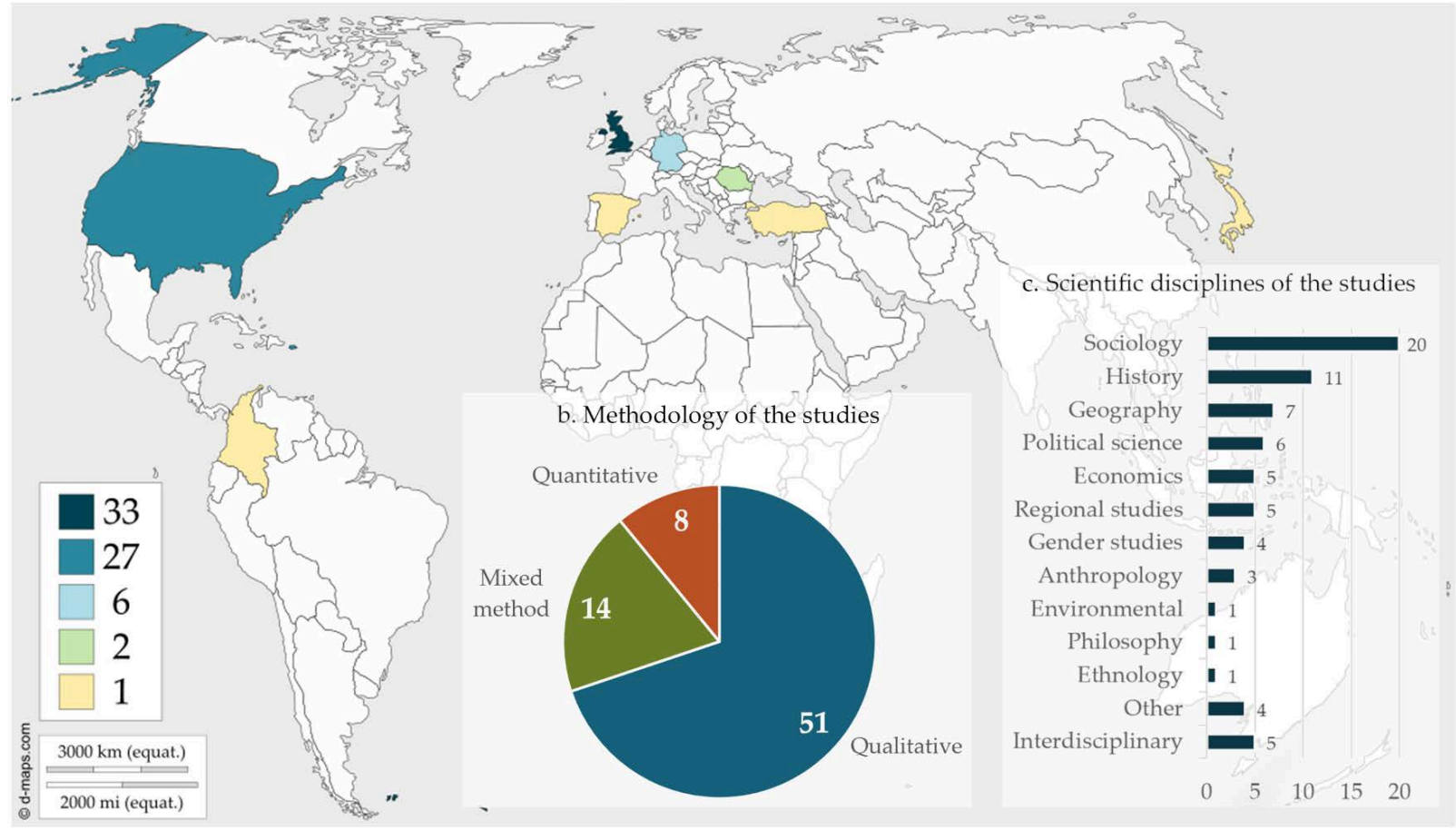

Figure 4. (a) Country distribution, (b) methodologies of the studies, and (c) scientific disciplines. Source: Own depiction, global map from d-maps [48].

The years of publication span from 1984 to 2020, covering transitions starting in Japan after the First World War [45] up to today. Studies on the effects of coal transitions in the UK and the USA, as well as on the UK's miners' strikes, have been published throughout the whole period (see Figure 5a).

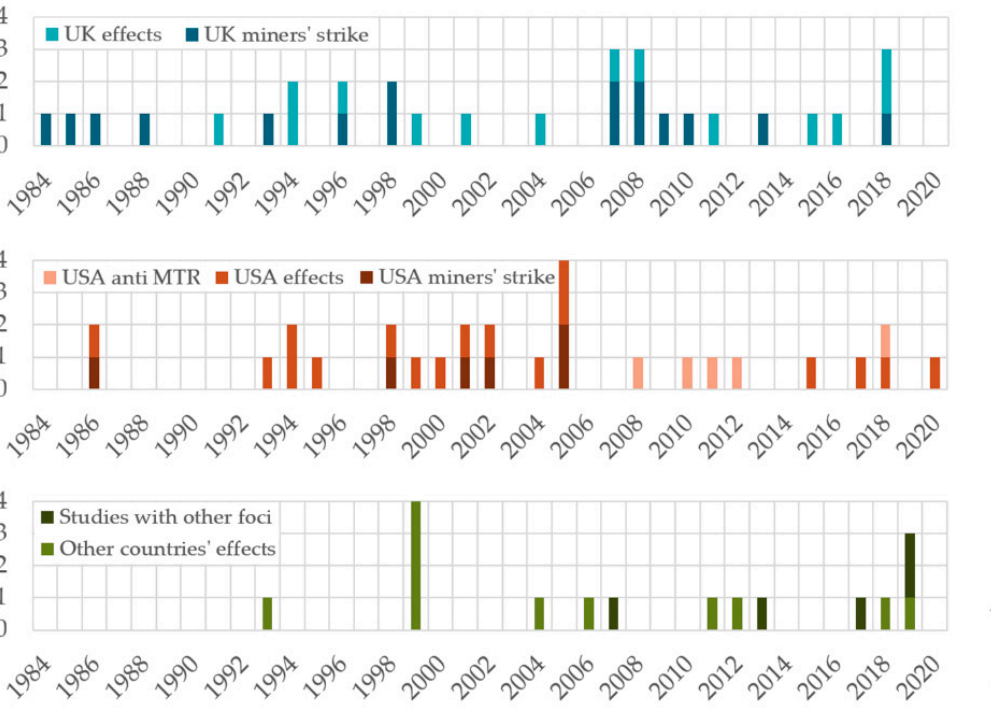

(a)

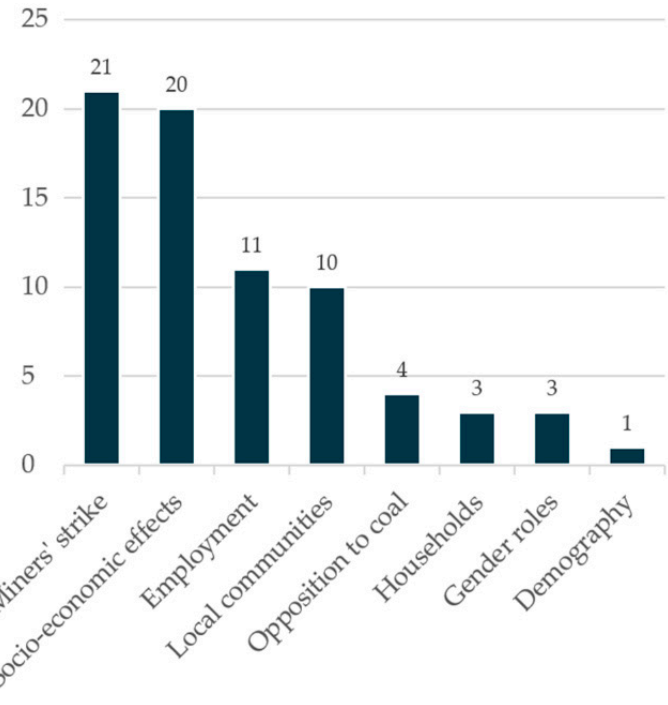

(b)

Figure 5. (a) Year of publication, divided by studies stemming from the UK, the USA, and other countries; (b) Focus of inquiry. Source: Own depiction. 
Turning towards the focus of inquiry (see Figure 5b), the miners' strikes in the USA and especially the UK [49-53] received broad attention, suggesting the great historical significance of these events. Despite the majority of the studies being based around pro-coal movements, our investigation also found four studies that focused on anti-coal activism by women living in coal regions, which started to be published around 15 years ago [11,54-56]. Socioeconomic effects as well as outcomes on the community level were also frequently discussed in the studies; this is described in detail in Section 3.2.

Gender interacts with other social statuses and identities, such as class, race, age, and religion. Together, they strongly influence a person's position in society and, consequently, the discrimination they face or privileges they enjoy. Introduced by Kimberlé Crenshaw [57] and further developed by many feminist scholars, the analytical framework of intersectionality has been widely used to describe the overlapping advantages and disadvantages that go hand in hand with the above-mentioned statuses and identities.

Figure 6 shows which categories were considered together with gender in the studies. It also shows whether the categories were taken into account comprehensively as a core concept in the study and thus played an overriding role alongside gender, or whether they were treated secondarily to gender as a side concept or were only mentioned in passing. Together with gender, class was an analytical lens in 46 out of the 73 studies, making it a highly relevant intersectional category for coal transitions. Especially in the miners' strikes in the UK from 1983-1984, class was essential to women's identities: "Class identity remains intact as a greater 'us', but women are now included within that" [58] (p. 230). Furthermore, beyond the UK, class was a relevant category in coal-mining communities across national borders and emerged in studies about almost all countries represented in the map $[9,33,43,59-61]$.

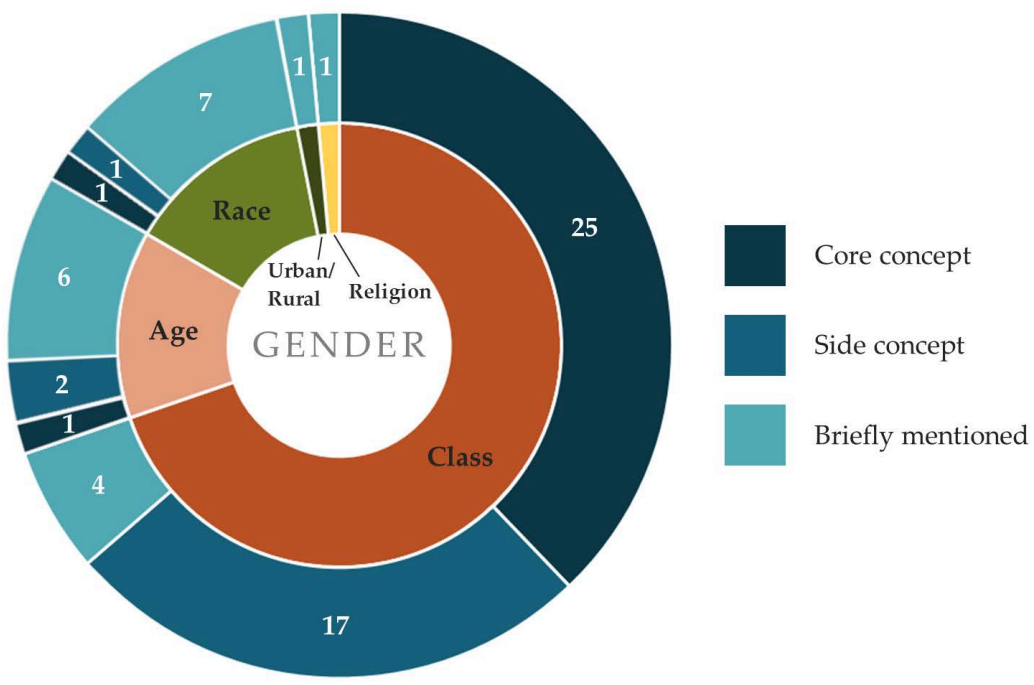

Figure 6. Intersectionality in the studies. Source: Own depiction.

Further relevant intersectional categories are race and age, both of which were addressed in 9 out of the 73 studies (see Figure 6). Most studies were concerned with the experiences of "white working class women" both for participation in miners' strikes as well as the transitions' outcomes $[50,62,63]$. However, the situation for women of colour was also treated in some texts, with Joyce Barry noting that "race has been a major framing device for Environmental Justice thought and activism, and [in anti-MTR activism,] people of colour have been at the forefront of this movement" [55] (p. 47). Age was also a relevant factor in the coal transitions. A woman's age entails different childcare duties, working experiences, and educational opportunities and therefore leads to different coping strategies and possibilities in transition moments $[64,65]$. 


\subsection{Reported Transition Effects on Women}

The following section reports the transition effects on women we found in the literature. The evidence was grouped into four areas of impact: gendered labour market effects and effects at the community, household, and individual levels.

\subsubsection{Gendered Labour Market Effects}

In wide-scale transition moments, the effects on local job markets hold particular relevance. In accordance with this, 40 studies reported outcomes within the primary job market-in our case, the coal industry-of which 24 reported job losses in general (usually mentioning that these mining jobs were largely occupied by men, e.g., Dublin and Licht 2000), 8 specifically reported job losses for men, and 2 reported reduced employment for women in the coal industry $[45,59]$. Furthermore, various studies emphasise the stark gender segregation of occupations, with men working in heavy industry, while women predominantly held factory jobs or performed care-based activities $[66,67]$. Before the transitions, gender differences in tasks and skills were rigid, as some of the coal regions had little other industry and thus scarce alternative employment opportunities for women, leading them to mainly perform unpaid work $[68,69]$. In sum, in the course of the transitions, the predominantly male workers were subject to massive layoffs, while the impact on women occurred in the secondary and tertiary job markets. In order to compensate for the decrease in household income, women increasingly took up paid jobs [70]. A total of 35 studies reported outcomes in the secondary and tertiary job market. Out of those 35,25 showed increased female employment rates in the aftermath of the transition [9,71,72]. Additionally, seven studies reported job gains in general, which-again due to gendered segregation of occupations-also meant an increase in female employment $[39,40,73]$. The conditions in these jobs are usually reported to be more precarious, low-paid, and insecure compared to the relatively secure mining jobs $[39,72,74,75]$. In contrast to the above findings, one study of the UK reported that after the mines closed, women lost employment in the manufacturing service sector, due to male ex-mine workers pushing them out of the job market [38]; similar but less substantiated findings can be found in [46].

\subsubsection{Effects on Community Level}

Since mining was often a large part of community life, social changes from the transitions were vast. In total, 56 of the 73 studies in the systematic map reported effects at the community level (see Figure 7a).
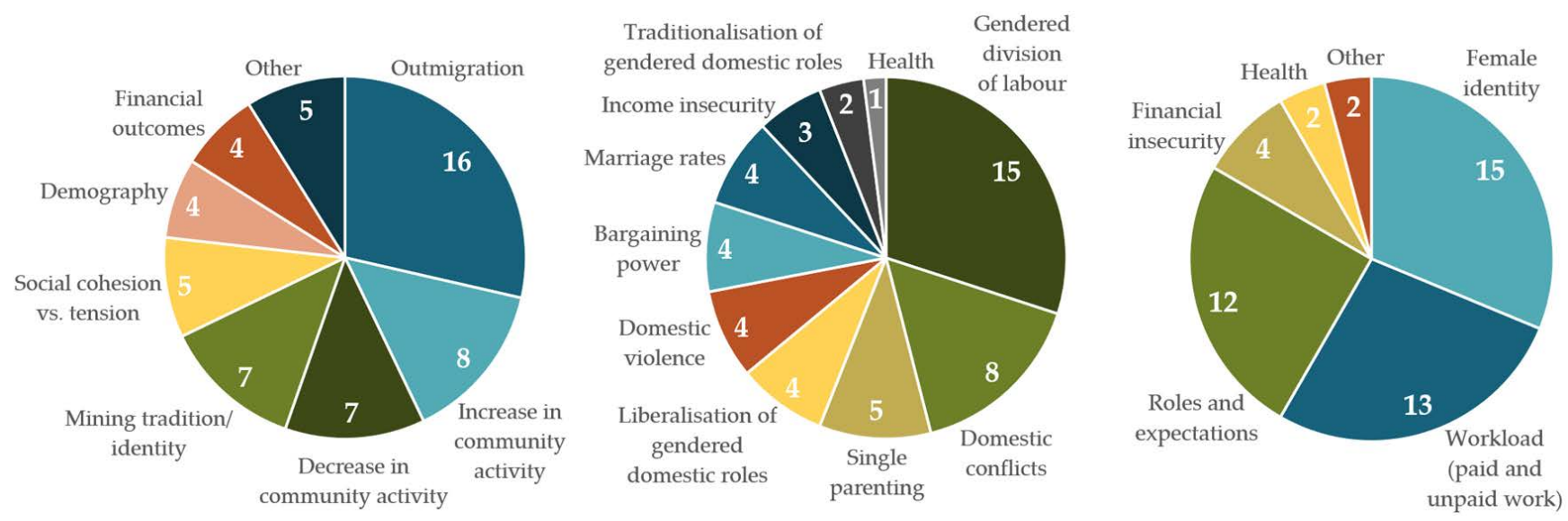

Figure 7. Studies reporting transition effects on women. (a) Effects on the community level; (b) Effects on the household level; (c) Effects on the individual level. Source: own depiction. 
The most prevalent effect of a coal transition was the deterioration of the corresponding locality due to outmigration. This was reported in $29 \%$ of the studies we examined, and we found different gendered outmigration patterns. For example, in Appalachia (USA) in the 1980s and 1990s, men migrated in high numbers in search of employment in construction or factory work [74]. In contrast, in Lusatia, former East Germany, it was mostly young women who left after the fall of the Iron Curtain (which was accompanied by a huge decline in the coal industry) to find employment outside their home region [76]. However, outmigration already affected some of the coal-mining areas before the transitions took place. For example, Barry [68] reported in a study focused on the USA that coal-mining operations were very loud and environmentally destructive, causing many people to move away; this in turn left mostly empty villages with deteriorating social and economic infrastructure.

The second-most affected area was community activity. Here we found nearly equal reports on increases and decreases in community activity due to the coal transition, with eight studies reporting an increase, while seven studies investigated a decrease (see Figure 7a). Often, an increase in community activity was reported during and after miners' strikes where women were involved [43]. People developed a stronger sense of community as they collectively (especially women) made the strike possible, for example, by supporting each other financially or with housework $[49,62,69,73]$. As one study on the UK miners' strikes put it: "The discrepancies between activism and ideological support for the strike confirm that people were active in the dispute as much because they had the time, the material resources and the opportunities to allow the possibility of giving support and wanted to help friends and neighbours in the close-knit community, as because of their commitment to the strike itself" [73] (p. 38).

Other studies argued that the necessity for women to become wage earners put heavy strains on community involvement, leading to reported decreases in community activity. This development was attributed to women being traditionally in charge of organising community events and maintaining social networks that they subsequently had no time for after entering the job market [39]. Furthermore, de-unionisation throughout the transition processes and conflicts during the strike weakened the community bond among former miners and led to further defragmentation within communities [33,60,75,77]. Hence, the development of social life remained unique to each community, and there was no unifying trend in social life accompanying these transitions.

In total, $13 \%$ of the studies reporting effects at the community level mentioned direct effects on the mining communities' identities. Coal communities often followed an especially patriarchal pattern. According to Maggard [9], this was connected to the coal industry itself, as gender inequality was exacerbated by the arrival of the industry in Appalachia. A historical study of the extent to which the arrival of the coal industry exacerbated gender segregation and by what mechanisms would be interesting but is beyond the scope of our research. Multiple studies reported that the transition away from coal weakened these traditional structures, as women broke out of their assigned sphere of the private $[49,51,69]$ (see below). In many cases, the image of mining communities became heavily romanticised after the coal transition, leading to the founding of institutions and clubs to preserve a long-gone mining identity and tradition [78]. Spence and Stephenson (2009) argued that the strong patriarchal tradition also influenced the way women were portrayed in British strikes. They showed that women were presented as only becoming politically active with the miners' strike. However, they found that this misrepresented women's participation in society before the transition. Many of them were already active before, for example, in community work. Mining as an identity was also affected in other ways, however. In the case of Romania, the transition destroyed trust among community members by pitting active miners that broke the strike (for various, often financial, reasons) against their former colleagues, who were then out of work [60]. 


\subsubsection{Effects at the Household Level}

While the two levels of affectedness elaborated above reflect wide-ranging effects, transition moments also change more small-scale structures, such as household dynamics. For an overview of the different effects found in 50 of our 73 studies, see Figure $7 \mathrm{~b}$.

In total, 15 out of $50(30 \%)$ studies reported a change in the gendered division of labour, making it the most prominent effect at the household level. Some studies on households in former coal communities in the UK reported that the new employment situation changed the division of labour, as men started to spend more time at home and women went out to work. As one study put it, "research suggest[s] subtle changes regarding the intersection of class and gender regimes in households that shape this former coalfield. [ ... ] there was growing intolerance of men doing nothing in the way of childcare and housework" [61] (p. 1296). Four studies reported a general liberalisation of gender roles $[39,49,58,79]$. In another study on the coal transition in the USA, it was said, "Men can no longer be the sole breadwinners and, because of declining birth rates, increasing access to education, and modern conveniences, women are less tied to the home. [ ... ] They [the women] can attempt to renegotiate a new 'gender contract' or leave the relationship all together." [39] (pp. 1055-1057). However, there is no clear pattern, as other studies also looking at the UK and the USA argued that the patriarchal gender division remained largely the same during and after the transition, often leaving the domestic work to women in addition to their paid jobs $[63,73]$. Various studies stated that the total workload for women increased, as their domestic tasks remained, but a new responsibility as wage earner was added $[73,80,81]$. In these cases, domestic tasks did not seem to have decreased substantially, as men started to be unemployed. Williams noted, "if a man did help out around the house, his assistance was given 'behind closed doors' and 'covertly in order to avoid embarrassment, and what might be interpreted as an affront to his manhood'" [81] (p. 69).

The second most reported outcome of coal transitions at the household level were domestic conflicts $[49,60,68]$. Four of the studies we evaluated even mentioned increases in domestic violence during the transition $[9,60,71,82]$. While the causes of domestic conflicts are manifold, the juxtaposition between women's traditional responsibilities in households and the changing nature of women's social positions through employment or political engagement and the resulting erosion of the traditional gendered order have to be seen among them $[60,66]$. One study mentioned that after the strikes against the mine closures in the UK were over, women were expected to return to their domestic roles as carers, which many refused to do [79].

\subsubsection{Effects at the Individual Level}

Effects on women at an individual level were reported in 48 studies (see Figure 7c). As already mentioned in the Section 3.2.2, Effects on Community Level, restructuring due to a coal transition had significant effects on the inhabitants' identities. In total, 15 out of the 48 studies addressing the impact on women at the individual level focused on how female identity changed during the transition $[52,59,73]$. Since identity is a broad concept, the aspects of female identity treated in each study vary greatly. In the UK miners' strikes, for example, traditional female gender norms changed abruptly. This forced a change in women's social identity and how they were seen within their community [75]. As Peter put it, "Instead of occupying a prominent position only within the female community hierarchy, their role in the strike was acknowledged by their recognition as important individuals by both women and men" [83] (p. 182). Another study, focusing on coping strategies of women in the face of economic challenges in Appalachia, recorded a fundamental change in the way women saw themselves through "increased self-esteem, confidence, and [in] gaining some financial independence" [74] (p. 64) by generating income, which in turn gave them a perception of themselves as role models for their daughters. Sometimes identity was not simply remodelled; one study from Spain reported a loss of identity for women based on class and their social status as 'miners' wives', due to the economic restructuring requiring they replace their role as the reproducing and caring counterpart to the male miners with 
new roles, based on a new sense of self. Young women in particular, recognising that the return to coal would only work in the short term, started to demand a more future-oriented perspective and a search for alternative ways to sustain their communities [43].

We can identify the clear pattern across studies and transitions that more women entered the labour market (see section on gendered labour market effects). Regarding the gendered division of labour, there is not such a clear pattern-some studies reported an increasing liberalisation of gender roles after the coal transition, while others reported that the addition of paid labour to the unpaid labour led to a double burden for many women (see section on the effects on household level). That the division of labour remained largely the same is likely to be due to the gender norms and expectations in the coal transition areas dealt with in 12 out of 48 studies (see Figure 7c). The highly gendered societal demands placed on women as care-givers and community upholders often remained $[41,84]$. These norms had been internalised over centuries, explaining cases in the UK where women remained content with traditional gender norms and avidly supported preserving the pre-transition social order. "Many [women of the support groups in UK] were keen to disassociate themselves from the more militant feminist groups who also became involved in strike support, and preferred to be seen as ordinary women from mining communities. They did not want to change their status within their communities; they were fighting for the stability of the world they knew" [52] (pp. 246-247).

\subsection{Female Agency in Historical Coal Transitions}

Just as women's social positioning influences outcomes, agency itself is also gendered within coal transitions. This is reflected in women's forms of organisation, their representation in decision-making bodies, and their visibility within coal transitions. Based on the definition of the term "agency" laid out in Section 2, we systematically analysed the information on female agency presented in the studies. In total, 26 out of the 73 studies treated agency as their main or sole focus, showing that female agency was a relevant aspect of coal transitions. As the following section shows, female agency both shapes, and is shaped by, transition processes.

Overall, $63 \%$ of the 26 studies reported that female actors were moderately or strongly against the coal transition in which they were involved, while $24 \%$ studies found women moderately or strongly in favour of it (see Figure 8). The other 13\% reported on female agency without explicitly stating their opinion.

12

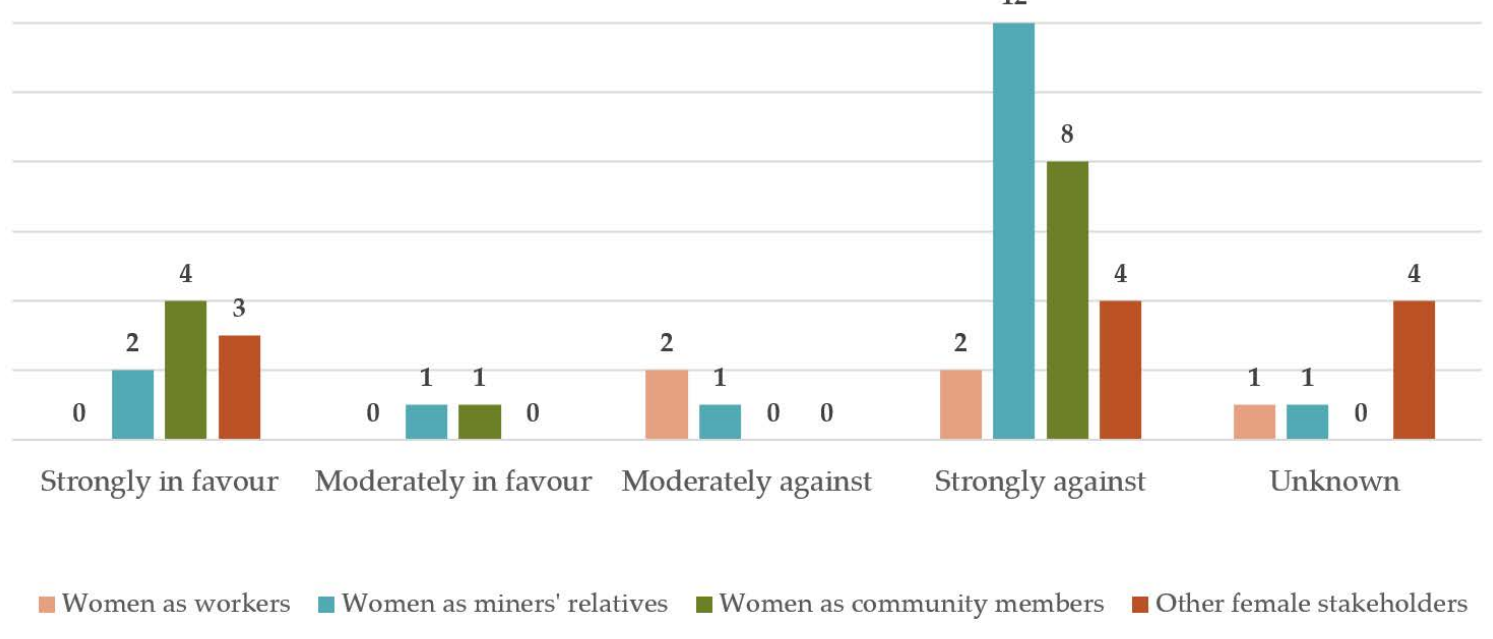

Figure 8. Female stakeholders' opinion on coal transition. Source: Own depiction.

Five studies from three publications covered the agency of women as coal workers. This particularly low number of studies reflects the predominance of male workers in coal 
mines in industrialised countries (e.g., $96.2 \%$ of the workforce in the USA coal industry is male [85] (p. 57)). This group of women were against or strongly against the transition, as it would inevitably entail losing their current jobs. Various studies reported that female miners tended to be dismissed [45] or demoted [59] before their male colleagues, indicating that coal transitions might hit female workers harder or earlier than male workers.

The agency of male miners' female relatives was covered in 17 publications, reporting mostly negative attitudes towards the transitions. For many women involved, saving the mines meant saving their homes and communities: "Salvar la mina es salvar los pueblos mineros" (translation from Spanish: Saving the mine is saving the mining villages) [43] (p. 94). In the UK, the USA, and Spain, women supported miners' strikes through informal but highly organised grassroots movements and thereby substantially increased the visibility of the male strikers $[43,51,53,62]$. Their activities ranged from collecting strike money, picketing, and establishing community kitchens, to more radical forms of action, such as occupation. Miners' support groups in the UK maintained close contacts with the National Union of Miners (NUM), although the form and intensity of cooperation were contentious among the women [53]. Most of the women's groups distanced themselves from feminist movements, identifying themselves as miners' relatives or working-class women rather than as feminists $[50,62,75]$. However, some texts mentioned ties to contemporary feminist movements or stated that the miners' wives were at least influenced by them $[49,53,73]$. Both women in pro-coal and anti-coal activism made arguments based on their identities as mothers or wives: their feelings of responsibility for the community and desire to preserve a living basis for their children incentivised them to become active. It was solely their judgements about what was best for their community that differed-either maintaining the current coal-based economy [53] or protecting the natural environment [11].

We also collected information on women who were not directly affected by mine closures in their family environment but were still involved in the process. A total of 13 studies contained information on the agency of women living in coal communities, and 11 studies treated the situation of women who were concerned with coal transition processes as stakeholders in other ways. Five of these publications examined female participation and leadership in environmental activism against MTR in the USA [11,55,56]. The activist women fought to protect their families from floods, toxins, air pollution, and other dangers caused by the MTR mining technique. They were driven to political action by direct threats to their families and communities, and often had no former experience in activism $[54,56]$. West Virginia, where MTR has been particularly prevalent since the 1990s, constituted a prominent example, with women forming organisations such as the "Coal River Mountain Watch". They educated themselves about the functioning of the coal industry in West Virginia and the supporting political conditions. Barry [54] reported that their personal self-esteem, their confidence to speak up for their interests, and their identity, apart from their traditional one as wife and mother, were strengthened due to their political activism. In contrast, other women were engaged in pro-coal lobbying in the same regions. Bell et al. [41] analysed the activities of the "Friends of Coal Ladies' Auxiliary", founded in 2007 as a sub-organisation of the "Friends of Coal". The female members were mostly white and middle class, and their husbands had ties to the coal industry. Through their activities, for example, at school events or in support of local residents with everyday problems, they tried to represent the coal industry positively in their communities. Further observations came from Kideckel [77], who directly addressed the absence of female agency in the transition process in the Jiu Valley in Romania, attributing this to institutional barriers as well as the responsibility of women to support their families, which increased as the economy declined.

Figure 9 summarises our findings regarding the political spheres of female agency in coal transition processes and reflects the fact that due to a lack of access to institutions and therefore structural power, women have mostly organised themselves informally in grassroots movements and community work $[37,53,83]$. In the UK, for example, barriers to access to the institutionalised power of the NUM were high; women were not allowed 
to participate in union meetings. Four years after the beginning of the strike, in 1987, some women were eventually granted associate membership-without voting rights. Most women's connection to the NUM was therefore based on family ties [53]. Beckwith argued that women's "indirect movement location [not being directly part of the NUM] also facilitated their activism" [50] (p. 1050). Members of the NUM were threatened with punishment, such as dismissal without compensation, while the women could mobilise and voice their opinion freely and thereby shape the anti-pit-closure discourse. Similar forms of organisation arose in the support of coal strikes in Spain and the USA [43,62]. The activism against MRT in the USA, mostly led by women, can also be considered grassroots work. It is to be noted that Coal River Mountain Watch and other anti-MTR groups were nowhere near as institutionalised and powerful as the UMWA (United Mine Workers of America) — even in its weakening state-particularly concerning the union's standing in formal institutions such as the government [56]. The forms of protest women chose varied widely, from more traditionally gendered tasks such as community kitchens, to non-violent protests, and even some accounts of violent protests. Moreover, some women engaged in local politics to pursue their interests and "create the conditions and policies that meet their multiple, yet overlapping, aspirations and responsibilities" [39] (p. 1060) or chose this form of organisation after the initial protests against mine closures were over [72].

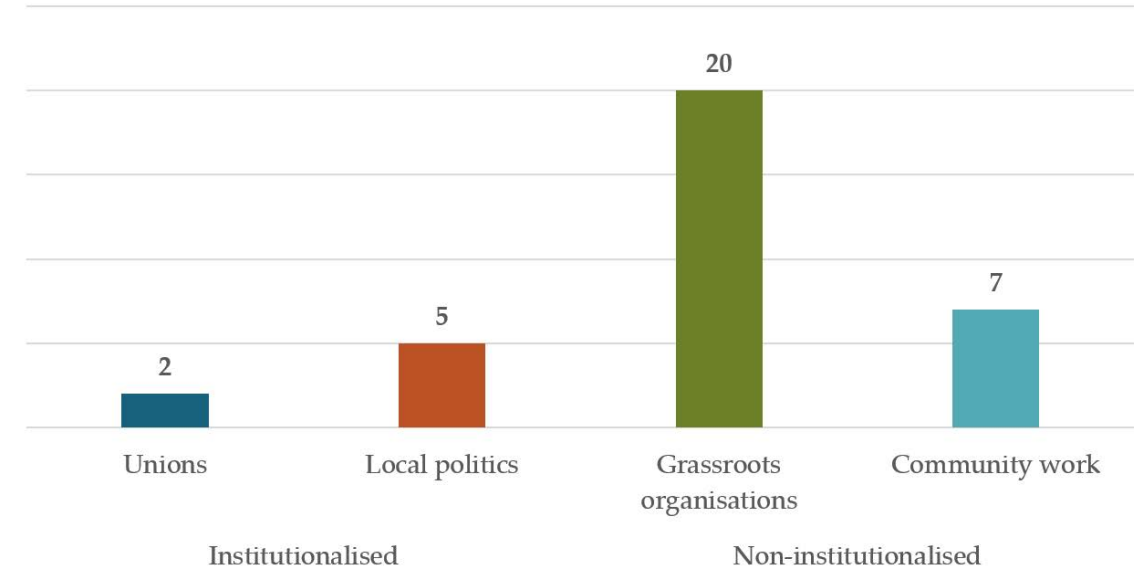

Figure 9. Political spheres of female agency. Source: Own depiction.

Various authors elaborated on the question of how increased female visibility and activism during coal transitions affected gender relations. Concerning the transition in Appalachia, Dublin and Licht [66] found that "gender roles were both reinforced and reconfigured during the collapse of the anthracite region's economy. The system of separate spheres for men and women persisted and even contributed to family survival, although certain role reversals occurred" (pp. 85-86). Maggard [82] noted that traditional understandings of gender were disrupted, and women who had not worked previously took up education and job training after participating in the strikes. Sanz Hernández and López Rodríguez [39] stated that in Spain, women moved from the private to the public sphere and from a passive role to an active one during their participation in the coal strikes. This changed their overall position in their communities. In the UK, female strike participation was reported to have had only a temporary effect on gender relations [50,51]. Phillips [72], on the contrary, stated that "[m]any women remained active politically after the strike [... ] and acquired formal educational qualifications" (p. 46), while still acknowledging that this was a slow, procedural process.

\section{Discussion and Research Agenda}

While there has been extensive academic research on coal transitions in general, there has only been a limited amount of academic literature from a gender perspective. Nevertheless, the existing research shows that women have been affected differently by 
historical coal phase-outs than men, and that women have chosen their own forms of participation in the transition processes.

A central question is if these results can be transferred to today's coal phase-out processes. Many socio-economic conditions have changed. In general, climate change considerations, prevalent today, were not the reasons for the historical coal transitions analysed in this paper; these coal phase-outs were mainly caused by economic factors. Moreover, the transitions were hardly cushioned by social policy. This could be one of the reasons why these transition processes were mainly opposed by the female stakeholders we analysed and why the tenor of the studies was mostly negative. Today, the climate crisis makes the coal phase-out urgent. Furthermore, there is a growing recognition of the need to support coal regions to develop alternative industries (e.g., through the European Just Transitions Fund [86]).

Our analysis of historical coal transitions shows that gender had a major impact on how a person was affected by the transition and to what extent she was involved in decision making. Even though many initial conditions have changed, we can conclude from our analysis and from the fact that gender is still very powerful in assigning men and women different positions in most areas of life that gender is also relevant for today's sustainability transitions [2]. We see a considerable lack of both quantitative and qualitative genderaggregated data and a need for more research to fully understand the gender dimension of today's sustainability transitions. Furthermore, novel policy instruments are needed to cushion the impacts of the transition on women, and consideration should be given to offering them more forms of participation besides their involvement in social dialogue

Only one of the ILO's just transition guidelines directly addresses the aspect of gender equality. However, we argue that gender should not be treated as just one aspect of the transition, but that the gender dimension runs through all aspects of transitions and should therefore be seen as an integral part of all the guidelines. Based on our findings on women in historical coal transitions, we have therefore developed a research agenda addressing all of the ILO's guidelines. This research agenda should facilitate a systematic scientific exploration of the gender perspective on today's just transitions away from carbon-intensive industries. Such research would contribute significantly to shaping gender-sensitive transition policies as well as gender-aware forms of participation. We recognise that meeting the ILO criteria alone would not lead to a just transition in the broader sense, as the ILO perspective merely focuses on carbon-intensive regions, and fails to address other important aspects of just transitions, such as energy and climate justice [87]. Nonetheless, meeting these criteria would be a first step towards a gender-just transition.

\section{(a) Participation}

The ILO's first principle of a just transition refers to the participation of all relevant stakeholders to ensure social consensus on the goals and pathways to a sustainability transition. This procedural dimension of justice is indeed key when it comes to the question of distributing the costs and benefits of transition processes in a fair way. Our research shows that women in coal regions have borne a relevant share of the transition costs and have had, for example, economic self-interests in transitions. However, due to their limited access to institutionalised decision-making processes and resources, their interests have not fully been taken into account.

To fulfil this ILO principle in future transition processes, greater efforts should be made to include the interests of women (and other marginalised groups). However, to fully integrate gender perspectives into transition processes, it is not enough to involve more women in decision-making processes. To develop gender-sensitive policies, the involvement of actors who are knowledgeable about gender aspects is necessary [88]. Future research on gender and sustainability transitions will be crucial for generating the required knowledge. This includes questions such as the following: What are the main interests, needs, and concerns of women affected by transitions? Which types of activities and forms of organisation do politically active women choose? What issues do they prioritise? Do 
they have access to resources (e.g., financial means or access to policymakers)? Has there been a shift in women's political activity in recent decades away from grassroots structures towards more formalised types of organisation because of improved access to such structures (e.g., unions, parties)? If not, how can the work of informally organised women be better transmitted to political bodies that shape transformation processes? Are there still barriers for women to join formal political organisations, such as unions or parties?

\section{(b) Rights at Work}

Policies must respect, promote, and bring about fundamental rights at work. This is the ILO's second principle. From a gender perspective, this principle is of great interest. Our research has shown that during and after a transition, more women entered the labour market, mainly taking up precarious and low-paid jobs in the service sector. Such a shift from industrial jobs to a more service-oriented regional economy can be expected in many future sustainability transitions. A fundamental question in this context is how to improve working conditions in the service sector. Another question concerns how women can be involved in the planning process at an early stage, before the transformation process is in full swing (see the first guideline above), to ensure that they have time to participate in training programmes, for example.

\section{(c) Gender Equality}

The third ILO principle directly addresses gender within sustainability transitions and states that policies and programmes must take into account the significant gender dimension of many environmental challenges and opportunities. We hope our research will help broaden the focus of this important point: not only environmental degradation but the transitions themselves and their consequences affect women differently than men. Historical coal transitions illustrate that the double burden of (usually unpaid) care work and paid work increased for women due to the transition. An interesting and important area of research to inform policymakers is the availability of care services in carbonintensive regions. Does the existing care infrastructure differ from other regions? To what extent does this care infrastructure depend on financial support from the carbon-intensive industry (e.g., corporate daycare centres)? Do the existing childcare services meet the needs of families/women? What is missing, and to what extent does this influence women's career planning and their ability to participate in the transition process?

We found multiple pieces of evidence in the literature that patriarchal structures are more pronounced in coal regions, and thus traditional gender norms are more persistent than in other regions. Further research could develop and test indicators of this relationship. A starting point could be to compare the distribution of care work between male and female household members or the identification with traditional role models between carbonintensive and other regions. If this correlation is confirmed, the causes for this discrepancy should also be researched further.

\section{(d) Coherence}

Energy policy and policymaking processes are dominated by a technocratic perspective. Economic perspectives are limited to energy prices, jobs, and labour, while social aspects are often neglected entirely $[3,20]$. This one-sidedness is also reflected in the ILO's mention of coherence, which states that policies in all areas should focus on the creation of an enabling environment for "enterprises, workers, investors and consumers to embrace and drive the transition towards environmentally sustainable and inclusive economies and societies." [16] (p. 6). What about the citizens, the community members, those who have left the workforce, or future generations? Coal phase-out processes have multiple social as well as economic impacts on these groups. Existing research mentions, for example, increased intra-household conflict, domestic violence, social tensions in communities, and outmigration. However, the scientific evidence is particularly thin concerning these aspects, and much more research is needed to understand what impacts (in addition to economic ones) low-carbon transitions have on communities and families, as well as how these 
impacts could be prevented or compensated for. On the other hand, research also provides examples of positive effects of coal transitions on women (intra-household empowerment, shifting traditional role models). The loss of (regional) identity is another aspect that is often discussed in the context of coal transitions. However, we did not find a significant amount of literature addressing this aspect from a female perspective. Future research could explore the question of whether women and men see the fossil-fuel industry as equally important for a given region. From studies on the attitudes of men and women toward the climate crisis, it can generally be said that women on average perceive the climate crisis as a greater threat [2]. Therefore, one research hypothesis would be that they also rate the coal phase-out as more urgent in order to overcome the climate crisis. Further research questions could be: Is the decline of the fossil-fuel industry accompanied by a loss of identity? Do women and men view it differently? It would also be of interest to better understand what empowering effects coal transitions have on women and how this could be considered in policymaking processes.

\section{(e) Employment}

The ILO's employment dimension emphasises the need to create a just transition for all. So far, however, transition policies have focused on compensating workers and communities directly affected by transitions away from fossil fuels [18]. This approach falls short, as indirectly affected workers in supporting sectors (e.g., the service sector) are not compensated, and job (re)training programmes are not designed for those who had mainly been engaged in unpaid care work or non-primary sectors before the transition. Since those working in the coal industry (and other carbon-intensive industries) are mainly men, while those working in the service sector and responsible for care work are mainly women, the gender-based injustice of this approach becomes clear. Further research should address this issue by collecting comprehensive data on the status quo in carbon-intensive regions, such as female employment rates and part-time employment rates in carbon-intensive regions compared to the respective national average. Are there differences between such regions, and if so, what are the reasons for this? It would also be of great value to have data on whether women want to enter the labour market, what barriers they have to overcome to do so, what skills and educational backgrounds women have, and what training opportunities are needed to give them better access to well-paid and secure jobs. A closer look at the career paths of women in energy companies would also be of value. Interesting questions could be, for example, whether there are gender differences in career paths after the closure of power plants or after the restructuring of energy companies towards more climate-friendly business fields (e.g., renewable energies).

Another relevant aspect related to employment is the integration of women into the social dialogue around sustainability transitions. Our research on historical transitions shows that it has been difficult for women to participate in union structures. Is this still the case, and if so, how can unions open their doors to women, and how can unions better represent the rights of workers in female-dominated professions?

(f) No "one size fits all"

The ILO's sixth principle underscores that there is no blueprint for a just transition, and that the appropriateness of certain policy instruments varies according to the specific conditions in each region. Likewise, women are not a homogeneous group of actors, but have very different life situations depending on their age, race, abilities, socioeconomic status, and educational background. This was at least somewhat reflected in the research we analysed for this study, and should always be taken into consideration when raising these research questions. For example, it would be worthwhile to conduct a detailed study on the different life situations of women from different backgrounds (e.g., in terms of class, race, age) and compare the ways they have been affected differently by energy transitions. Furthermore, it would be interesting to compare the situations of women working in the service sector across different countries that are either facing an energy transition or are in the middle of one. What differences exist among countries? How have some countries 
managed to build better working conditions in female-dominated professions? Which policy instruments are effective, and why?

\section{(g) International Cooperation}

The last ILO principle focuses on international cooperation. In this respect, our research has its limitations. Due to our focus on historical coal transitions, we ended up with a dataset that focused on industrialised countries in the Global North. This limits the validity of our research to the Global North, which means we do not take into account the specific circumstances faced by women in the Global South. However, in the first phase of our literature search, we came across a number of studies that we ultimately had to exclude from our analysis in a later step that dealt with ongoing coal transitions or with transitions in other mining sectors such as gold mining. It is likely that this literature provides some insights into transition processes in the Global South that could lead to recommendations for just transition policies. It would be an interesting future research project to, for example, compile the literature on agency of women in current coal disputes in another systematic map. In Colombia, for example, Afro-Colombian and indigenous women play an important role in grassroots movements fighting for better protection of their land from dangerous and polluting coal mining [89].

\section{Conclusions}

The low-carbon transition that needs to be implemented in all sectors of the economy to mitigate the catastrophic effects of unlimited global warming affects different social groups differently and creates unequal chances for these groups to voice their opinions depending on their position in society. It is the task of science to examine the different needs and interests of these various groups-for example, women, who unfortunately still have different starting conditions and resource endowments than men-and thus develop a basis for fair structural policies for all social groups.

The conviction that low-carbon transitions should be implemented as fairly as possible for all parties involved (i.e., a just transition) has gained ground in international discourse in recent years. The gender dimension of climate and environmental policies is also recognised by major international political organisations such as the UN in its SDGs (Sustainable Development Goals). However, there is little scientific basis so far for gender-sensitive transition policies, because scholars looking at the consequences of lowcarbon transitions often merely analyse broader economic effects (e.g., net employment effects) on entire regions, rather than the effects that transitions have on actor groups other than predominantly male miners. Addressing this issue, we developed a research agenda which leads to a better understanding of the interrelationship between gender and low-carbon transitions.

To develop such a research agenda, it was essential to gain an overview of all existing empirical information on this topic. To this end, we have conducted a systematic map that was as comprehensive as possible, containing publications dealing with our research question - the impact of historical coal transitions on women and their role in it. In the process of compiling the systematic map, we read over 3100 abstracts of potentially relevant publications obtained through a systematic literature search. After title and abstract screening, we identified 247 texts that could be relevant to our research question and read them in full text. In total, 73 studies contained relevant results, which we then analysed. Based on these studies, we identified the most important links between coal transitions and gender and developed a research agenda corresponding to the ILO guidelines for just transitions with essential questions that need to be investigated to make structural policies more gender-sensitive in the future.

We found various effects that historical coal phase-out processes had on women; these very much depended on the country context and the living reality of each woman. However, there are still some general statements we can make.

Previous coal transitions have often led to women entering the labour market, as many men in the coal industry lost their jobs and thus income. These women found employment 
especially in the service sector where, on average, the pay was significantly lower and the working conditions worse than in male-dominated sectors. Even though the economic situation for many families in former coal-mining regions worsened in general, women in those families gained some financial independence due to their increased employment; this strengthened their self-esteem and confidence. However, the lack of childcare services also led to an increased double burden and limited women's career opportunities. The coal phase-out process additionally changed community life within coal regions. Often whole communities participated, for example, in miners' strikes, which strengthened their sense of community. Women contributed significantly to these activities and networked the community members. On the other hand, with advancing coal phase-outs, women in former coal regions had less and less time to do community work as they traditionally had done due to their increased double work burden. In addition, structural change in the context of the coal phase-out had an impact on household cohabitation. In some cases, men and women were able to reorganise the division of labour in the household, as women increasingly took up employment. In other cases, however, the increasing change in the male breadwinner model had negative effects and led to intra-family conflicts and even violence.

Just as women's social positioning influences the effects that coal transitions have on them, agency within coal transitions is also gendered. Women have been active in both pro-coal and anti-coal movements. Regarding pro-coal movements, we found information on women's roles in miners' strikes in the UK, the USA, and Spain. It was difficult for women to gain access to union structures, which led them to organise themselves into grassroots movements. They took up a variety of actions, from fundraising and setting up community kitchens to more radical actions, such as occupation. Women also played a large role in anti-coal movements, such as the fight against MTR (Mountain-Top Removal) in the USA. These grassroots groups were largely established by women. One reason for this is that men had closer ties to the coal industry. Activism in both pro-coal and anti-coal movements - even though this activism has been restricted by patriarchal structures in society - has often empowered women and increased their self-confidence.

Based on these findings, we identified the following key issues that need to be addressed scientifically in order to achieve a gender-just transition.

1. How can women's interests be better integrated into low-carbon transition processes?

2. How can working conditions be improved in female-dominated sectors?

3. How can care work be distributed more fairly (within families and within society)?

4. What non-economic effects (e.g., identity loss, conflicts, domestic violence) do transitions have on carbon-intensive regions, and how do these affect women differently than men?

5. How can the restructuring of local employment opportunities be designed to lead to more gender equity?

6. How can the different, intersecting life situations (age, class, race) of women affected by low-carbon transitions better be taken into account?

Furthermore, we found only a relatively small number of relevant studies in spite of a complex and extensive research process, which shows that the topic is still underresearched. In general, much more gender-aggregated qualitative and quantitative data are needed. In sum, we agree with Garcia-Garcia et al. [20] that failing to consider "the gender implications of the energy transition is an analytical bias we can no longer afford" (p. 13), since women, due to their social positioning in society, are very differently affected by lowcarbon transitions and have different opportunities to shape it politically compared to men. Understanding their needs and positions more thoroughly is key to ensuring an economically and socially successful transition.

Author Contributions: Conceptualization, I.B., P.W., C.B., J.S., and P.-Y.O.; methodology, I.B., P.W., C.B., and J.S.; software, C.B. and J.S.; validation, P.W., I.B., J.S., C.B., and P.-Y.O.; formal analysis, I.B., P.W., C.B., and J.S.; investigation, I.B., P.W., C.B., and J.S.; resources, P.-Y.O.; data curation, J.S. and 
C.B.; writing-original draft preparation, I.B., P.W., J.S., and C.B.; writing-review and editing, I.B., P.W., J.S., C.B., and P.-Y.O.; visualization, C.B. and J.S.; supervision, P.-Y.O., I.B., and P.W.; project administration, P.-Y.O., I.B., and P.W; funding acquisition, P.-Y.O. and C.K. All authors have read and agreed to the published version of the manuscript.

Funding: We gratefully acknowledge support granted from the German Ministry of Education and Research (BMBF) by financing the research group "CoalExit" [grant number 01LN1704A] as part of the "Global Change" funding priority and from the European Union's Horizon 2020 research and innovation program funding the CINTRAN project [grant agreement No. 884539]. Isabell Braunger and Paula Walk gratefully acknowledge funding from the graduate program "The Great Transformation" from Heinrich-Böll-Stiftung.

Acknowledgments: We thank Biljana Macura for her very helpful feedback on our search protocol. We are grateful to Jürgen-Michael Loch for his support in the development of our search string. We want to thank Nora Stognief for her support and Felipe Corral-Montoya, Marius Koepchen, Katharina Whrolig, Julia Schmieder, and Virginia Sondergeld for their very helpful feedback. We thank Teresa Gehrs and Matt Rees for language corrections. All potentially remaining errors are ours.

Conflicts of Interest: The authors declare no conflict of interest. The funders had no role in the design of the study; in the collection, analyses, or interpretation of data; in the writing of the manuscript; or in the decision to publish the results.

\section{Appendix A}

Table A1. Queries to databases on 3 June 2020.

\begin{tabular}{|c|c|c|c|c|c|}
\hline Portal & Databases & Access Provided by & Search Term & Further Limitation & \# of Results \\
\hline $\begin{array}{l}\text { Scopus } \\
\text { (Elsevier) }\end{array}$ & Not applicable & $\begin{array}{l}\text { Humboldt- } \\
\text { Universität zu Berlin } \\
\text { (HU Berlin) }\end{array}$ & 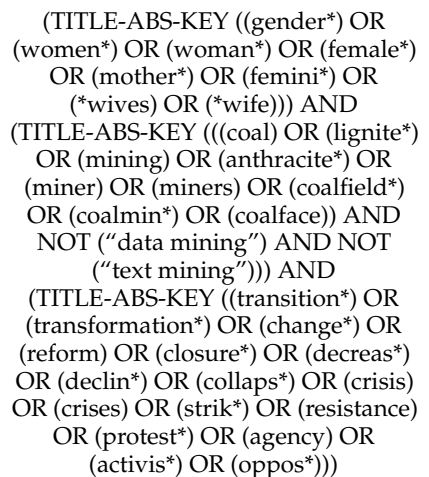 & $\begin{array}{l}\text { Search limited to Title, } \\
\text { Abstracts, Keywords; } \\
\text { Subject areas limited to } \\
\text { Environmental Sciences, } \\
\text { Social Sciences, Arts } \\
\text { and Humanities, Earth } \\
\text { and Planetary Sciences, } \\
\text { Business Management } \\
\text { and Accounting, } \\
\text { Multidisciplinary, } \\
\text { Economics } \\
\text { Econometrics and } \\
\text { Finance, Psychology, } \\
\text { Energy, Undefined }\end{array}$ & 1256 \\
\hline Web of Science & $\begin{array}{c}\text { Science Citation Index } \\
\text { Expanded (SCI-EXPANDED) } \\
\text { Social Sciences Citation } \\
\text { Index (SSCI) } \\
\text { Arts \& Humanities Citation } \\
\text { Index (A\&HCI) } \\
\text { Conference Proceedings } \\
\text { Citation Index- Science } \\
\text { (CPCI-S) } \\
\text { Conference Proceedings } \\
\text { Citation Index-Social } \\
\text { Science \& Humanities } \\
\text { (CPCI-SSH) } \\
\text { Book Citation Index-Science } \\
\text { (BKCI-S) } \\
\text { Book Citation Index- Social } \\
\text { Sciences \& Humanities } \\
\text { (BKCI-SSH) } \\
\text { Emerging Sources Citation } \\
\text { Index (ESCI) }\end{array}$ & $\begin{array}{l}\text { Technische } \\
\text { Universität Berlin } \\
\text { (TU Berlin) }\end{array}$ & $\begin{array}{l}\text { not applicable (sum of single searches, } \\
\text { not generated automatically) }\end{array}$ & $\begin{array}{l}\text { List too long for table, } \\
\text { see below: } 1\end{array}$ & 520 \\
\hline
\end{tabular}


Table A1. Cont.

\begin{tabular}{|c|c|c|c|c|c|}
\hline Portal & Databases & Access Provided by & Search Term & Further Limitation & \# of Results \\
\hline 更 & $\begin{array}{c}\text { ABI/INFORM Collection } \\
\text { Applied Social Sciences } \\
\text { Index \& Abstracts (ASSIA) } \\
\text { British Periodicals } \\
\text { Digital National Security } \\
\text { Archive } \\
\text { ERIC } \\
\text { PAIS Index } \\
\text { Periodicals Archive Online } \\
\text { Periodicals Index Online } \\
\text { Sociological Abstracts } \\
\text { Worldwide Political Science } \\
\text { Abstracts }\end{array}$ & $\begin{array}{l}\text { Technische } \\
\text { Universität Berlin } \\
\text { (TU Berlin) }\end{array}$ & 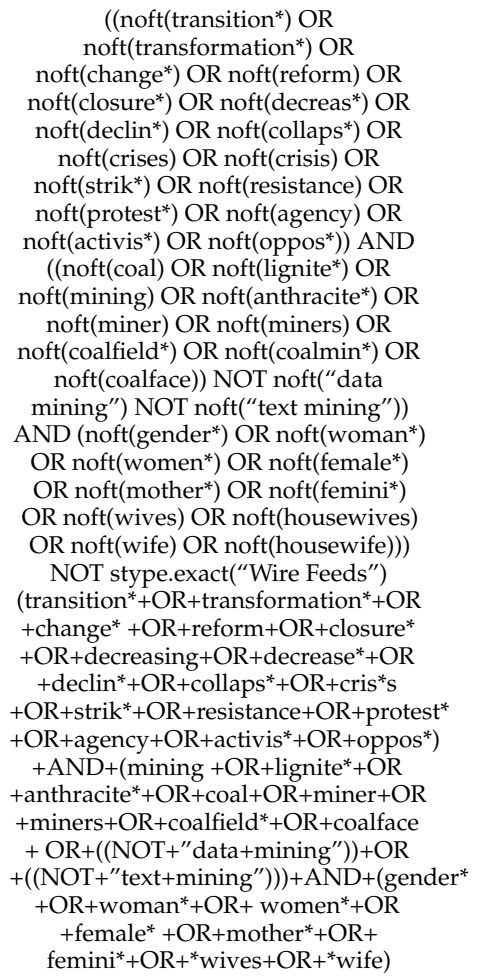 & $\begin{array}{c}\text { noft }=\text { all fields } \\
\text { excluding full text } \\
\text { newspaper feeds } \\
\text { excluded } \\
\text { does not allow for * } \\
\text { before word, * } \\
\text { wife/wives } \\
\text { supplemented by } \\
\text { wife/wives and } \\
\text { housewife/wives }\end{array}$ & 1632 \\
\hline
\end{tabular}

${ }^{1}$ Additional parameters Refined by: [excluding] WEB OF SCIENCE CATEGORIES: (HEALTH CARE SCIENCES SERVICES OR PUBLIC ENVIRONMENTAL OCCUPATIONAL HEALTH OR BIOTECHNOLOGY APPLIED MICROBIOLOGY OR TOXICOLOGY OR NUCLEAR SCIENCE TECHNOLOGY OR ENTOMOLOGY OR IMMUNOLOGY OR PHYSIOLOGY OR NEUROSCIENCES OR SPORT SCIENCES OR PARASITOLOGY OR SURGERY OR WATER RESOURCES OR VETERINARY SCIENCES OR ENDOCRINOLOGY METABOLISM OR ONCOLOGY OR PSYCHIATRY OR GEOCHEMISTRY GEOPHYSICS OR COMPUTER SCIENCE INFORMATION SYSTEMS OR NURSING OR ZOOLOGY OR ORNITHOLOGY OR ORTHOPEDICS OR BIOCHEMISTRY MOLECULAR BIOLOGY OR EVOLUTIONARY BIOLOGY OR BIOLOGY OR TROPICAL MEDICINE OR RESPIRATORY SYSTEM OR UROLOGY NEPHROLOGY OR MEDICINE GENERAL INTERNAL OR METALLURGY METALLURGICAL ENGINEERING OR CHEMISTRY ANALYTICAL OR PHARMACOLOGY PHARMACY OR METEOROLOGY ATMOSPHERIC SCIENCES OR CHEMISTRY MULTIDISCIPLINARY OR COMPUTER SCIENCE THEORY METHODS OR CLINICAL NEUROLOGY OR MEDICINE RESEARCH EXPERIMENTAL OR COMPUTER SCIENCE INTERDISCIPLINARY APPLICATIONS OR DERMATOLOGY OR AGRONOMY OR ENGINEERING CHEMICAL OR INFECTIOUS DISEASES OR BIOCHEMICAL RESEARCH METHODS OR FISHERIES OR RADIOLOGY NUCLEAR MEDICINE MEDICAL IMAGING OR BIOPHYSICS OR FORESTRY OR GENETICS HEREDITY OR CARDIAC CARDIOVASCULAR SYSTEMS OR EDUCATION EDUCATIONAL RESEARCH OR COMPUTER SCIENCE ARTIFICIAL INTELLIGENCE OR MICROBIOLOGY OR PLANT SCIENCES OR HORTICULTURE OR OBSTETRICS GYNECOLOGY OR PSYCHOLOGY MULTIDISCIPLINARY OR MEDICINE LEGAL OR MARINE FRESHWATER BIOLOGY OR REPRODUCTIVE BIOLOGY OR PEDIATRICS OR BIODIVERSITY CONSERVATION OR AGRICULTURE MULTIDISCIPLINARY OR CELL BIOLOGY OR CHEMISTRY APPLIED).

\section{References}

1. IPCC. Global Warming of $1.5^{\circ} \mathrm{C}$; An IPCC Special Report on the Impacts of Global Warming of $1.5^{\circ} \mathrm{C}$ above Pre-Industrial Levels and Related Global Greenhouse Gas Emission Pathways, in the Context of Strengthening the Global Response to the Threat of Climate Change, Sustainable Development, and Efforts to Eradicate Poverty; IPCC: New York, NY, USA, 2018.

2. Spitzner, M.; Hummel, D.; Stieß, I.; Alber, G.; Röhr, U. Interdependente Genderaspekte der Klimapolitik; Umweltbundesamt: DessauRoßlau, Germany, 2020.

3. Lieu, J.; Sorman, A.H.; Johnson, O.W.; Virla, L.D.; Resurrección, B.P. Three Sides to Every Story: Gender Perspectives in Energy Transition Pathways in Canada, Kenya and Spain. Energy Res. Soc. Sci. 2020, 68, 101550. [CrossRef]

4. International Energy Agency (IEA) CO2 Emissions by Energy Source, World 1990-2018 in Percent. Available online: https:// www.iea.org/data-and-statistics / data-browser?country=WORLD\&fuel=CO2\%20emissions\&indicator=CO2BySource (accessed on 13 July 2021).

5. Yanguas Parra, P.; Hauenstein, C.; Oei, P.-Y. The Death Valley of Coal-Modelling COVID-19 Recovery Scenarios for Steam Coal Markets. Appl. Energy 2021, 288, 116564. [CrossRef]

6. IEA. Net Zero by 2050: A Roadmap for the Global Energy Sector; International Energy Agency: Paris, France, 2021.

7. National Association of State Energy Officials. Energy Futures Initiative. U.S. Energy and Employment Report; NASEO: Arlington, VA, USA; EFI: Washington, DC, USA, 2018. 
8. Janikowska, O.; Kulczycka, J. Just Transition as a Tool for Preventing Energy Poverty among Women in Mining Areas-A Case Study of the Silesia Region, Poland. Energies 2021, 14, 3372. [CrossRef]

9. Maggard, S.W. From Farm to Coal Camp to Back Office and McDonald's: Living in the Midst of Appalachia's Latest Transformation. J. Appalach. Stud. Assoc. 1994, 6, 14-38.

10. Brown, B.; Spiegel, S.J. Coal, Climate Justice, and the Cultural Politics of Energy Transition. Glob. Environ. Polit. 2019, 19, 149-168. [CrossRef]

11. Bell, S.E.; Braun, Y.A. Coal, Identity, and the Gendering of Environemntal Justice Activism in Central Appalachia. Gend. Soc. 2010, 24, 794-813. [CrossRef]

12. Daggett, C. Petro-Masculinity: Fossil Fuels and Authoritarian Desire. Millenn. J. Int. Stud. 2018, 47, 25-44. [CrossRef]

13. Haddaway, N.R.; Macura, B. The Role of Reporting Standards in Producing Robust Literature Reviews. Nat. Clim. Change 2018, 8 , 444-447. [CrossRef]

14. Haddaway, N.R.; Macura, B.; Whaley, P.; Pullin, A.S. ROSES RepOrting Standards for Systematic Evidence Syntheses: Pro Forma, Flow-Diagram and Descriptive Summary of the Plan and Conduct of Environmental Systematic Reviews and Systematic Maps. Environ. Evid. 2018, 7. [CrossRef]

15. Pullin, A.; Frampton, G.; Livorleil, B.; Petrokofsky, G. Collaboration for Environmental Evidence. Guidelines and Standards for Evidence Synthesis in Environmental Management. Version 5.0. Available online: http:/ /www.environmentalevidence.org/ information-for-authors (accessed on 4 June 2020).

16. ILO. Guidelines for a Just Transition towards Environmentally Sustainable Economies and Societies for All; International Labour Organization: Geneva, Switzerland, 2015.

17. Freepik Offene Schriftrolle Umriss Kostenlose Icons. Available online: https:/ / de.freepik.com/freie-ikonen/offene-schriftrolleumriss_735778.htm (accessed on 7 September 2021).

18. Piggot, G.; Boyland, M.; Down, A.; Raluca Torre, A. Realizing a Just and Equitable Transition Away from Fossil Fuels; SEI: Stockholm, Sweden, 2019.

19. Gambhir, A.; Green, F.; Pearson, P.J.G. Towards a Just and Equitable Low-Carbon Energy Transition; Imperial College London: London, UK, 2018.

20. García-García, P.; Carpintero, Ó.; Buendía, L. Just Energy Transitions to Low Carbon Economies: A Review of the Concept and Its Effects on Labour and Income. Energy Res. Soc. Sci. 2020, 70, 101664. [CrossRef]

21. United Nations. Just Transition of the Workforce, and the Creation of Decent Work and Quaility Jobs; United Nations Framework Convention on Climate Change: Bonn, Germany, 2018.

22. UNFCCC Paris Agreement; United Nations Framework Convention on Climate Change: Paris, France, 2015.

23. James, K.L.; Randall, N.P.; Haddaway, N.R. A Methodology for Systematic Mapping in Environmental Sciences. Environ. Evid. 2016, 5, 7. [CrossRef]

24. Coole, D. Agency. Encycl. Polit. Theory 2010, 3, 11-13.

25. Davies, B. The concept of agency: A Feminist Poststructuralist Analysis. Soc. Anal. Int. J. Soc. Cult. Pract. 1991, $42-53$.

26. Butler, J. Gender Trouble Feminism and the Subversion of Identity; Routledge: New York, NY, USA, 1990; ISBN 9781280316838.

27. Alaimo, S.; Hekman, S.J. (Eds.) Material Feminism; Indiana University Press: Bloomington, IN, USA, 2008 ; ISBN 9780253349781.

28. Young, I.M. Lived Body vs Gender: Reflections on Social Structure and Subjectivity. Ratio 2002, 15, 410-428. [CrossRef]

29. O'Connor, D.; Green, S.; Higgins, J.P. Defining the Review Question and Developing Criteria for Including Studies. In Cochrane Handbook for Systematic Reviews of Interventions; Higgins, J.P., Green, S., Eds.; John Wiley \& Sons, Ltd.: Chichester, UK, 2008; pp. 81-94; ISBN 9780470712184.

30. Cadima. Available online: https:/ / www.cadima.info/ (accessed on 23 June 2020).

31. Mahood, Q.; Van Eerd, D.; Irvin, E. Searching for Grey Literature for Systematic Reviews: Challenges and Benefits. Res. Synth. Methods 2014, 5, 221-234. [CrossRef] [PubMed]

32. Statista Coal Production in Chile from 2010 to 2019. Available online: https:/ /www.statista.com/statistics/1174991/chile-coalproduction-volume/ (accessed on 28 April 2021).

33. Smith, B.E. Another Place Is Possible? Labor Geography, Spatial Dispossession, and Gendered Resistance in Central Appalachia. Ann. Assoc. Am. Geogr. 2015, 105, 567-582. [CrossRef]

34. Dalingwater, L. Neo-Liberalism and Gender Inequality in The Workplace in Britain. Fr. J. Br. Stud. 2018, 1. [CrossRef]

35. BP. Statistical Review of World Energy; BP p.l.c.: London, UK, 2020.

36. Beckwith, K. Collective Identities of Class and Gender: Working-Class Women in the Pittston Coal Strike. Polit. Psychol. 1998, 19, 147-167. [CrossRef]

37. Gier-Viskovatoff, J.J.; Porter, A. Women of the British Coalfields on Strike in 1926 and 1984: Documenting Lives Using Oral History and Photography. Front. J. Women Stud. 1998, 19, 199-230. [CrossRef]

38. Aragón, F.M.; Rud, J.P.; Toews, G. Resource Shocks, Employment, and Gender: Evidence from the Collapse of the UK Coal Industry. Labour Econ. 2018, 52, 54-67. [CrossRef]

39. Miewald, C.E.; McCann, E.J. Gender Struggle, Scale, and the Production of Place in the Appalachian Coalfields. Environ. Plan. A 2004, 26, 1045-1064. [CrossRef]

40. Oberhauser, A.M. Industrial Restructuring and Women's Homework in Appalachia: Lessons from West Virginia. South. Geogr. 1993, 33, 23-43. [CrossRef] 
41. Bell, S.E.; Fitzgerald, J.; York, R. Protecting the Power to Pollute: Identity Co-Optation, Gender, and the Public Relations Strategies of Fossil Fuel Industries in the United States. Environ. Sociol. 2019, 5, 323-338. [CrossRef]

42. Braunger, I.; Walk, P. Gender Implications of Sustainability Transitions: Women's Living Realities in UK and US Historical Coal Transitions. Forthcoming.

43. Sanz Hernández, A.; López Rodríguez, M.E. Mujeres Del Carbón. Protestas y Emociones En La Reesetructuración Minera Española. Aposta Rev. Cienc. Soc. 2017, 74, 84-110.

44. Sengül, H.T.; Aytekin, A.E. Zonguldak Coalfield and the Past and Future of Turkish Coal-mining Communities. In Changing Work and Community Identities in European Regions Perspectives on the Past and Present; Kirk, J., Contrepois, S., Jefferys, S., Eds.; Palgrave Macmillan: New York, NY, USA, 2012; pp. 154-184.

45. Mathias, R. Female labour in the Japanese coal-mining industry. In Japanese Women Working; Hunter, J., Ed.; Routledge: London, UK, 1993; pp. 99-121; ISBN 978-0-415-12791-2.

46. Arango, L.; Flórez, L.; Olarte-Delgado, M. Precio Del Carbón y Dinámica Laboral En Valledupar. Rev. Econ. Rosario 2019, 22, 313-370. [CrossRef]

47. Botta, E. A Review of "Transition Management" Strategies: Lessons for Advancing the Green Low-Carbon Transition; OECD Green Growth Papers; OECD: Paris, France, 2019.

48. d-maps Map Planisphere World (Europe Africa). Available online: https://d-maps.com/carte.php?num_car=13181\&lang=en (accessed on 1 July 2021).

49. Miller, S. "The Best Thing That Ever Happened to Us": Women's Role in the Coal Dispute. J. Law Soc. 1985, 12, 355-364. [CrossRef]

50. Beckwith, K. Lancashire Women against Pit Closures: Women's Standing in a Men's Movement. Signs 1996, 21, 1034-1068. [CrossRef]

51. Spence, J.; Stephenson, C. Female Involvement in the Miners' Strike 1984-1985: Trajectories of Activism. Sociol. Res. Online 2007, 12, 1-11. [CrossRef]

52. Davies, R. "Not Just Supporting But Leading": The Involvement of the Women of the South Wales Coalfield in the 1984-85 Miners' Strike. Ph.D. Thesis, University of Glamorgan, Pontypridd, UK, 2010.

53. Sutcliffe-Braithwaite, F.; Thomlinson, N. National Women Against Pit Closures: Gender, Trade Unionism and Community Activism in the Miners' Strike, 1984-1985. Contemp. Br. Hist. 2018, 32, 78-100. [CrossRef]

54. Barry, J. “A Small Group of Thoughtful, Committed Citizens": Women's Activism, Environmental Justice, and the Coal River Mountain Watch. Environ. Justice 2008, 1, 25-33. [CrossRef]

55. Barry, J. Standing Our Ground: Women, Environmental Justice, and the Fight to End Mountaintop Removal; Ohio University Press: Athens, Greece, 2012.

56. McNeil, B.T. Combating Mountaintop Removal: New Directions in the Fight against Big Coal; University of Illinois Press: Chicago, IL, USA, 2011.

57. Crenshaw, K. Mapping the Margins: Intersectionality, Identity Politics, and Violence against Women of Color. Stanf. Law Rev. 1991, 43, 1241-1299. [CrossRef]

58. Stephenson, C.; Spence, J. Pies and Essays: Women Writing through the British 1984-1985 Coal Miners' Strike. Gend. Place Cult. 2013, 20, 218-235. [CrossRef]

59. Clemens, P.; Rauhut, S. Rapportbuch: Frauen Im Kraftwerk Und in Der Kohle, 1957 Bis 1996; Trafo: Berlin, Germany, 1999; ISBN 9783896261526 .

60. Kideckel, D. Miners and Wives in Romania's Jiu Valley: Perspectives on Postsocialist Class, Gender, and Social Change. Identities 2004, 11, 39-63. [CrossRef]

61. Bennett, K. Women and Economy: Complex Inequality in a Post-Industrial Landscape. Gend. Place Cult. 2015, 22, 1287-1304. [CrossRef]

62. Seitz, V.R. Class, Gender and Resistance in the Appalachian Coalfields. In Community Activism and Feminist Politics. Organizing across Race, Class and Gender; Naples, N., Ed.; Routledge: London, UK, 1998; pp. 213-236.

63. Schell, K.S.; Silva, J.M. Resisting Despair: Narratives of Disruption and Transformation among White Working-Class Women in a Declining Coal-Mining Community. Gend. Soc. 2020, 34, 736-759. [CrossRef]

64. Ali, M. The Coal War: Women's Struggle during the Miners' Strike. In Caught up in Conflict: Women's Responses to Political Strife; Women in Society; Ridd, R., Callaway, H., Eds.; Macmillan Education: London, UK, 1986; pp. 84-105; ISBN 9781349183807.

65. Jung, Y.-S. Just a Housewife? Miners' Wives between Household and Work in Postwar Germany. In Mining Women: Gender in the Development of a Global Industry, 1670 to 2005; Gier, J.J., Mercier, L., Mercier, L., Eds.; Palgrave Macmillan: New York, NY, USA, 2006; pp. 262-279.

66. Dublin, T.; Licht, W. Gender and Economic Decline: The Pennsylvania Anthracite Region, 1920-1970. Oral Hist. Rev. 2000, 27, 81-97. [CrossRef]

67. Oberhauser, A.M.; Turnage, A.-M.; Smith, B. A Coalfield Tapestry: Weaving the Socioeconomic Fabric of Women's Lives. In Neither Separate Nor Equal: Women, Race and Class in the South; Temple University Press: Philadelphia, PA, USA, 1999; pp. 109-122.

68. Barry, J. Mountaineers Are Always Free?: An Examination of the Effects of Mountaintop Removal in West Virginia. Womens Stud. Q. 2001, 29, 116-130.

69. Spence, J.; Stephenson, C. “Side by Side With Our Men?” Women's Activism, Community, and Gender in the 1984-1985 British Miners' Strike. Int. Labor Work.-Cl. Hist. 2009, 75, 68-84. [CrossRef] 
70. Beatty, C. Two Become One: The Integration of Male and Female Labour Markets in the English and Welsh Coalfields. Reg. Stud. 2016, 50, 823-834. [CrossRef]

71. Bennett, K. A Time for Change? Patriarchy, the Former Coalfields and Family Farming. Sociol. Rural. 2004, 44, 147-166. [CrossRef]

72. Phillips, J. The Meanings of Coal Community in Britain since 1947. Contemp. Br. Hist. 2018, 32, 39-59. [CrossRef]

73. Measham, F.; Allen, S. In Defence of Home and Hearth? Families, Friendships and Feminism in Mining Communities. J. Gend. Stud. 1994, 3, 31-45. [CrossRef]

74. Oberhauser, A.M. Gender and Household Economic Strategies in Rural Appalachia. Gend. Place Cult. J. Fem. Geogr. 1995, 2, 51-70. [CrossRef]

75. Spence, J. Women, Wives and the Campaign against Pit Closures in County Durham: Understanding the Vane Tempest Vigil. Fem. Rev. 1998, 60, 33-60. [CrossRef]

76. Jacobsen, H.; Winkler, A. Gewinnerinnen und Verlierer. Strukturbrüche Auf Dem Arbeitsmarkt im Transformationsprozess am Beispiel der Stadt Cottbus_Eine Erste Analyse; Lehrstuhl für Wirtschafts- und Industriesoziologie; BTU: Cottbus, Germany, 2011.

77. Kideckel, D. Coal Power: Class, Fetishism, Memory, and Disjuncture in Romania's Jiu Valley and Appalachian West Virginia. ANUAC 2018, 7, 67-88. [CrossRef]

78. Dawson, A. The Poetics of Self-Depreciation: Images of Womanhood amongst Elderly Women in an English Former Coal Mining Town. Anthropol. J. Eur. Cult. 2000, 9, 37-51.

79. Shaw, M.; Mundy, M. Complexities of Class and Gender Relations: Recollections of Women Active in the 1984-5 Miner's Strike. Cap. Cl. 2005, 29, 151-174. [CrossRef]

80. Dublin, T.; Licht, W. The Face of Decline; Cornell University Press: Ithaca, NY, USA, 2016; ISBN 9781501707308.

81. Williams, M.A. Aspects of Women's Working Lives in the Mining Communities of South Wales, c 1891-1939. Folk Life 1999, 38, 56-70. [CrossRef]

82. Maggard, S.W. Gender and Schooling in Appalachia: Historical Lessons for an Era of Economic Restructuring; West Virginia University, Regional Research Institute: Morgantown, WV, USA, 1994.

83. Peter, G. Analysing the British Miners' Strike of 1984-5. Econ. Soc. 1988, 17, 139-194. [CrossRef]

84. Marshall, J. Imagining Futures in Changing Locales: De-Industrialisation and Education Work Interfaces. Ph.D. Thesis, Cardiff University, Cardiff, UK, 2008.

85. McWilliams, L.J.; Lenart, P.J.; Lancaster, J.L.; Zeiner, J.R. National Survey of the Mining Population Part I: Employees; Information Circular 9527; Department of Health and Human Services: Pittsburgh, PA, USA, 2012; p. 266.

86. European Commission Just Transition Funding Sources. Available online: https://ec.europa.eu/info/strategy/priorities-2019-2 024/european-green-deal/actions-being-taken-eu/just-transition-mechanism/just-transition-funding-sources_en (accessed on 6 July 2021).

87. Carley, S.; Konisky, D.M. The Justice and Equity Implications of the Clean Energy Transition. Nat. Energy 2020, 5, 569-577. [CrossRef]

88. Kronsell, A. Gender and Transition in Climate Governance. Environ. Innov. Soc. Transit. 2013, 7, 1-15. [CrossRef]

89. Mohr, K.; Rojas Castro, S.; Meyer, K.; Mahecha Groot, A.M.; Natalia, D.N.; María Laura, R.V. Gender Responsive Climate Policy. A Case Study of the Colombian Coal Sector; Polis 180: Berlin, Geramny, 2020. 